FEDERAL RESERVE BANK OF SAN FRANCISCO

WORKING PAPER SERIES

\title{
Aggregation Level in Stress Testing Models
}

\author{
Galina Hale, John Krainer \\ Federal Reserve Bank of San Francisco \\ Erin McCarthy \\ University of British Columbia
}

September 2015

Working Paper 2015-14

http://www.frbsf.org/economic-research/publications/working-papers/wp2015-14.pdf

\section{Suggested citation:}

Hale, Galina, John Krainer, and Erin McCarthy. 2015. “Aggregation Level in Stress Testing Models.” Federal Reserve Bank of San Francisco Working Paper 2015-14.

http://www.frbsf.org/economic-research/publications/working-papers/wp2015-14.pdf

The views in this paper are solely the responsibility of the authors and should not be interpreted as reflecting the views of the Federal Reserve Bank of San Francisco or the Board of Governors of the Federal Reserve System. 


\title{
Aggregation Level in Stress Testing Models*
}

\author{
Galina Hale, John Krainer ${ }^{\dagger}$ \\ Federal Reserve Bank of San Francisco \\ Erin McCarthy \\ University of British Columbia
}

September 28, 2015

\begin{abstract}
We explore the question of optimal aggregation level for stress testing models when the stress test is specified in terms of aggregate macroeconomic variables, but the underlying performance data are available at a loan level. Using standard model performance measures, we ask whether it is better to formulate models at a disaggregated level ("bottom up") and then aggregate the predictions in order to obtain portfolio loss values or is it better to work directly with aggregated models ("top down") for portfolio loss forecasts. We study this question for a large portfolio of home equity lines of credit. We conduct model comparisons of loan-level default probability models, county-level models, aggregate portfolio-level models, and hybrid approaches based on portfolio segments such as debt-to-income (DTI) ratios, loan-to-value (LTV) ratios, and FICO risk scores. For each of these aggregation levels we choose the model that fits the data best in terms of in-sample and out-of-sample performance. We then compare winning models across all approaches. We document two main results. First, all the models considered here are capable of fitting our data when given the benefit of using the whole sample period for estimation. Second, in out-of-sample exercises, loan-level models have large forecast errors and underpredict default probability. Average out-of-sample performance is best for portfolio and county-level models. However, for portfolio level, small perturbations in model specification may result in large forecast errors, while county-level models tend to be very robust. We conclude that aggregation level is an important factor to be considered in the stress-testing model design.
\end{abstract}

JEL classification: G21, G28, C18, C52.

Keywords: bank stress testing, forecasting, portfolio granularity, probability of default, mortgage, home equity

*The views expressed here are those of the authors and not necessarily those of the Federal Reserve Bank of San Francisco or the Federal Reserve System. The authors thank Michael Bauer, Paul Calem, Kris Gerardi, Jose Lopez, Joe Tracy, Paul Willen, as well as participants of the Interagency Risk Quantification Forum, the 2015 IBEFA conference, 2015 the FRB-Atlanta policy conference for very helpful discussions. All errors are our own.

${ }^{\dagger}$ galina.b.hale@sf.frb.org and john.krainer@sf.frb.org

${ }^{\ddagger}$ mccarthy.erink@gmail.com 


\section{Introduction}

Under the Dodd-Frank Act, the Federal Reserve is required to conduct annual stress tests of the systemically-important U.S. banking institutions 11 The centerpiece of the supervisory stress tests is a calculation of expected losses for banks under a set of economic scenarios. A scenario consists of explicit paths for macroeconomic and financial market variables such as interest rates, asset prices, unemployment, inflation, and GDP growth. Thus, both the design and the outcome of interest in the stress test are specified at the aggregate level. The scenarios are not necessarily considered likely: no probabilities are attached to individual scenarios. However, the scenarios are meant to be coherent in the sense that, even though some variables, such as unemployment, may move to extreme values, other variables in the scenario, such as credit spreads, should comove with these extreme changes in historically consistent ways. Individual institutions as well as the Federal Reserve use loss forecasting models to project losses under different scenarios. Our paper demonstrates that data aggregation level should be an important factor in modeling decision.

Given the distinct structure of supervisory stress tests, our research question centers on which risk modeling and forecasting approaches may prove to be most useful for the task at hand. Specifically, if the goal is to predict total losses and the inputs to the stress test are given at a certain level of aggregation, what is the desired level of aggregation of underlying loan portfolio variables in the risk modeling? In this paper we investigate whether different levels of portfolio aggregation yield different degrees of forecasting error and stability, and sensitivity to macroeconomic variables $2^{2}$ Our application is to a portfolio of home equity lines of credit (HELOCs) observed over the 20022013 period for which we estimate default frequency. We consider "bottom-up" loan-level models,

\footnotetext{
${ }^{1}$ The Federal Reserve has conducted several distinct rounds of stress testing since the financial crisis in 20087. Both the Supervisory Capital Assessment Program (SCAP) of 2009, and the Comprehensive Capital Analysis and Review (CCAR) are very similar in terms of format. The principal change in supervisory stress testing over the past several years has been the increase in number of institutions included in the exercise

${ }^{2}$ By forecast stability we mean low sensitivity of estimates to changes in data sample or small perturbations of the model specification.
} 
where we incorporate very detailed information on loan characteristics as well as local and aggregate economic variables. We also consider "top-down" time-series models at the portfolio level $[3$ Finally, we evaluate hybrid approaches where we aggregate the data into buckets by deciles of the risk factors, or by county. The goal of the paper is to provide an out-of-sample forecast evaluation of these models and assess which levels of aggregation work best in terms of mean-squared error (MSE) of forecast as well as a loss functions that only penalize under-prediction of the default probability.

A number of theoretical considerations weigh on the choice of which level to aggregate the data to. At one extreme, a top-down approach would have us use fairly simple specifications to capture the time-series dynamics of home equity default rates. This level of aggregation also fits with the loss function of a bank regulator, which would emphasize default rates or losses at an aggregate or firm level rather than at the individual loan level. The disadvantage of using highly aggregated data, of course, is that these models are almost always misspecified. These models will perform poorly if the composition of loans is changing over time, as was recently the case in U.S. housing markets when a period of easing underwriting standards led to a large expansion of credit to previously constrained borrowers 4 There is also a risk that the aggregation process introduces aggregation bias, where parameters estimated at a macro-level deviate from the true underlying micro parameters . $^{5}$

While loan-level models offer solutions to the problems associated with the "top-down" approach, their use also presents challenges. Traditionally, two main obstacles to estimating loan-level default

\footnotetext{
${ }^{3}$ See Hirtle, Kovner, Vickery, and Bhanot (2014) for comparison of overall stress-testing results produced by "top-down" and "bottom-up" models.

4 Frame, Gerardi, and Willen (2015) show how this changing loan composition led to large errors in the default model predictions used by the Office of Federal Housing Enterprise Oversight to stress Fannie Mae and Freddie Mac's exposure to mortgage default risk.

${ }^{5}$ Going back to Theil (1954), linear models that are perfectly specified at the micro-level were known to be susceptible to aggregation bias. Grunfeld and Griliches (1960) showed that once this assumption of a perfectly specified micro model is relaxed, then aggregation could produce some potential gains in the form of aggregating out specification or other types of measurement error. Also, Granger (1980) shows that time series constructed from aggregated series can have substantially different persistence properties than is present in the underlying disaggregated data.
} 
models have been the lack of reliable loan-level data and computational limits. This is much less of a problem in the current day, given recent improvements in data collection in the banking and financial sector and computing technologies. However, many of the risk factors that enter into loan-level default models are actually market-level proxies of the individual borrower's risk factor. For example, housing values (i.e., the value of the collateral for the loans) are not updated regularly at the individual borrower level. In our analysis we update the loan-to-value ratio (LTV) using a county or zip code house price index. This introduces measurement error into the estimation, which may be nonrandom. We encounter the same measurement problem with the unemployment rate, which we proxy for with a county-wide unemployment rate. The home-owning and home equity borrowing population may be quite different from the population in a county most exposed to unemployment shocks. Indeed, for the case of unemployment, there is a further complication. Ideally, we would have a variable telling us whether the borrower him or herself is unemployed 6 But what in fact we have is a population average probability that the borrower is unemployed (see also Gyourko and Tracy (2013)). Such use of proxies tends to lead to an attenuation bias, or a propensity to find a weaker estimated relationship between two variables of interest than is in fact present. This bias seems particularly worrisome given the design of the Federal Reserve's stress tests which are cast in terms of exactly these variables where we have measurement difficulties at loan level.

Given these challenges of both "top-down" and "bottom-up" approaches, it is interesting to evaluate intermediate levels of aggregation. We consider county-level models, the level at which data on macroeconomic variables of interest are usually available. This level of aggregation addresses the potential problem with attenuation bias in loan-level models. We also consider models in which data are aggregated to portfolio segments by FICO score, LTV, and DTI, thus addressing the problem of changing portfolio composition that "top-down" models face.

\footnotetext{
${ }^{6}$ There is evidence that borrowers are not completely strategic in their default behavior and require a "double trigger" of house price declines and unemployment (Gerardi, Herkenhoff, Ohanian, and Willen $(2013)$ ).
} 
In order to evaluate different levels of aggregation with respect to the stress testing usefulness, we need to choose an empirical specification for each. It turns out that the set of model specifications with good fit are different for different aggregation levels. For this reason we proceed in three steps: first we screen a very large number of specifications that include all potential risk drivers at various lags, as well as their interactions, for statistical significance, intuitive sign, in-sample and out-of-sample fit. This is done using some judgement (e.g., house prices should enter into any model of home equity default), as well $R^{2}$, information criteria, and forecast error. Then we focus on a smaller number of reasonable specifications that pass the screening test. For each of these specifications, we estimate regressions using data ending in each of 12 months from June 2008 through July 2009. In each case, we construct the forecasted default frequency for the following 9 quarters, in the spirit of CCAR exercises, and compute mean standard errors of forecast (MSEs) as well as measures of how conservative the forecast is.

We find that across all these specifications, county-level regressions tend to have lower forecast errors, produce reasonably conservative results, and are quite stable across specification and forecast windows. Loan-level regressions tend to have the highest forecast errors and the least conservative predictions, while aggregate regressions perform well on average but are not very robust to specification changes. Models aggregated by risk factor deciles also perform quite well and are relatively stable across specifications. They are, however, inferior to county-level regressions in terms of the forecast error. Thus, in the case of home equity lines of credit default projection, neither loan-level not top-down aggregate models are best for CCAR purposes. In our exercise the best approach is to aggregate the data to some extent - most meaningfully, to the level at which macroeconomic variables used in scenarios are available, the county level.

While we do not presume that this specific result immediately generalizes to other portfolios, we conclude that level of aggregation is an important factor to consider in any stress-testing loss modeling. The analysis of optimal level of aggregation became possible with the increased availability 
of loan- or other micro-level data. Too often, however, the modelers simply assume that the most disaggregated level of analysis is the best one. We hope that our paper will encourage regulators as well as practitioners to consider aggregation level as one of the parameters in the modeling process.

The paper is organized as follows. In section 2 we demonstrate that econometric theory does not provide a clear guide as to which level of aggregation will result in the lowest forecasting error. We illustrate the way that disaggregated models (i.e., loan-level risk models in our application) may suffer from measurement error, while the most aggregated top-down risk models may suffer from aggregation bias. In section 3 we describe the home equity data set we use. We detail the specifics of our forecasting exercise and results in Section 4 . Section 5 concludes.

\section{Econometric framework}

Our goal is to predict default rate $y \in[0,1]$ on the entire portfolio given macroeconomic scenarios. The macroeconomic variables $x$ do not vary by loan in portfolio, although some macroeconomic variables might vary by geographical segments of portfolio. For simplicity of notation, suppose we are only predicting one period forward, that is predicting $y_{T+1}$ given $x_{T+1}$ and observed history of $y$ 's and $x$ 's up to period $T$. Suppose the data generating process (DGP) is such that

$$
y_{t}=X^{\prime} \beta+\varepsilon,
$$

where $y$ is a vector of observed default rates (or, in case of individual loans, default indicators) over time, $X$ is a matrix of observed covariates, including constant term, unobserved disturbance $\varepsilon$ is distributed $N\left(0, \sigma^{2}\right)$. We can use linear regression to estimate $b$, the estimator for $\beta$, and $\hat{\sigma}$, the estimator for $\sigma$.

Suppose $y$ and $X$ are observed at individual loan level, and there are $N$ loans observed for $T$ time periods. Therefore, we have a choice of whether to estimate $b$ and $\hat{\sigma}$ on individual loan data 
(using linear probability regression for the ease of exposition), on average values of $y$ and $X$ for sub-portfolios of any type (using pooled or fixed effects panel regression), or on overall portfolio averages (using time series regression). Given that our goal is to predict aggregate $y$, we want to determine which method is preferable.

Regardless of the regression estimated, the forecast can be constructed by substituting $b$ for $\beta$ in the DGP equation above. For now, let us assume that regardless of the aggregation level, we can obtain an unbiased estimate of $\beta$. Therefore, aggregation level will not affect the expected forecast mean.

In case of unbiased estimates, therefore, we are only concerned with the precision of our forecast. Assume that all the individual observations are i.i.d. Let's denote $y_{L}$ and $X_{L}$ the observables measured at loan level, $y_{P}$ and $X_{P}$ those at portfolio level, and $y_{B}$ and $X_{B}$ those at sub-portfolio, or bucket, level. Portfolio and sub-portfolio variables can be expressed as averages of loan-level data:

$$
y_{P}=\frac{1}{N} S_{N}^{\prime} y_{L}, \quad X_{P}=\frac{1}{N} S_{N}^{\prime} X_{L},
$$

where $S_{N}$ is an $(N T \times T)$ summation matrix such that each element of $y_{P}$ and each row of $X_{P}$ are sums of elements in a given time $t 7$ Similarly,

$$
y_{B}=\frac{1}{J} S_{J}^{\prime} y_{L}, X_{B}=\frac{1}{J} S_{J}^{\prime} X_{L},
$$

where $1<J<N$ is the number of sub-portfolios, $S_{J}$ is an $(N T \times J T)$ summation matrix such that each element of $y_{B}$ and each row of $X_{B}$ is the sum for a given $t$ of all the elements of subportfolio j.8

\footnotetext{
${ }^{7} S_{N}=I_{T} \otimes 1_{N}$, where $I_{T}$ is a $(T \times T)$ identity matrix and $1_{N}$ is a vector of $\mathrm{N}$ ones.

${ }^{8} S_{J}=I_{T} \otimes I_{J} \otimes 1_{N_{J}}$ in a special case of all subportfolios having the same number of observations, so that $J * N_{J}=N$.
} 
One can show that differences in Brier score for predicting $y_{T+1}$ using regressions with different level of aggregation will be determined by differences in estimated variance of the disturbance term $\hat{\sigma}$, the number of loans and sub-portfolios, and differences in inverse sum of squared covariates. If the observations are i.i.d., different aggregation levels will give the same results in the limit. However, in finite samples, even if observations are drawn from i.i.d. distributions, there will be differences in forecast errors, depending on a sample. They will generally be larger the more aggregated the regression sample is.

There are two main reasons, however, to believe that the observations in the analysis are not i.i.d. and therefore the estimates of $\beta$ are not necessarily unbiased: namely, measurement error and aggregation bias, to which we now turn.

\subsection{Individual-level measurement error}

One issue that arises in loan-level analysis is that macroeconomic variables are not measured at a loan level. For example, while a borrower's unemployment status or home price have a direct effect on his or her probability to default on the home equity loan, it is common to proxy for these variables with state or MSA-level unemployment rate and home price index, which introduces measurement error problem in loan-level regressions. With sufficient number of observations per state or MSA, these individual errors cancel out when computing averages for the state or MSA-level regressions, so the problem is specific to loan-level regressions.

Formally, let's define observables $Z$, a subset of $X$, that is only observable at aggregation level of sub-portfolios. Thus, for loan $i$ in subportfolio $j$ and time $t$, the true covariate $Z_{i j t}$ is

$$
Z_{i j t}=\bar{Z}_{j t}+\zeta_{i j t}
$$

where $\zeta$ is unobserved and is distributed with mean zero and variance $\varsigma^{2}$. When $\bar{Z}_{j t}$ is used instead 
of unobserved $Z_{i j t}$ in the regressions, they suffer from an omitted variable bias, due to correlation between the regressor $\bar{Z}_{j t}$ and the error term, which now is $\varepsilon_{i j t}+\zeta_{i j t}$. Thus, the estimator $b_{L}$ is no longer unbiased. To see this, denote as $\tilde{X}$ the subset of regressors in $X$ that is not $Z$ combined with observable $\bar{Z}$. The unbiased estimators would be produced by the regression

$$
y=\tilde{X}^{\prime} b+\zeta^{\prime} c+e
$$

Since $\zeta$ is unobserved, we estimate instead the regression

$$
y=\tilde{X}^{\prime} \tilde{b}+\tilde{e}
$$

We can show that

$$
E(\tilde{b})=\beta+\left(\tilde{X}^{\prime} \tilde{X}\right)^{-1} \tilde{X}^{\prime} \zeta c
$$

Given that in general, $\bar{Z}$ and $\zeta$ are correlated, $\tilde{X}$ and $\zeta$ are correlated, and therefore $\tilde{b}$ will not be an unbiased estimator of $\beta$. If the correlation is positive and $c>0$ or if correlation is negative and $c<0, E(\tilde{b})>\beta$, otherwise, $E(\tilde{b})<\beta$. Since $c$ and $\zeta$ are not observed, it is generally not possible to evaluate on pure econometric basis whether the bias is positive or negative. Note that an attenuation bias would be particularly harmful if the estimates are used for scenario analysis, because lower coefficients on macroeconomic variables would lead to an underestimate of the stress scenario losses.

Moreover, one can show that

$$
E\left(\tilde{e}^{\prime} \tilde{e}\right)-E\left(e^{\prime} e\right)=\hat{\sigma}_{L}^{2} * k_{2}+c^{\prime} \zeta^{\prime} \zeta c
$$

that is, the sum of squared errors and therefore the forecast error will always be larger in the 
presence of measurement error.

Given that we assumed that the measurement error is zero on average for each $j$, the level of aggregation at which $Z$ is observed, such a problem will only arise for loan-level regressions, not for portfolio, or $j$-level regressions.

\subsection{Aggregation bias}

The measurement error problem has to be weighed against the aggregation bias problem. In the prior discussion we assumed that $x_{i j t}$ and $e_{i j t}$ are uncorrelated across individual loans $i$. This assumption is necessary to obtain $b_{P}$ and $b_{B}$ that are unbiased estimates of $\beta$. In practice, this is unlikely to be the case. If $\forall t E\left(x_{i t} x_{j t}\right) \neq 0, E\left(e_{i t} e_{j t}\right) \neq 0$, for $i \neq j$, aggregate regression estimates will not be unbiased. More specifically,

$b_{P}=\left(X_{P}^{\prime} X_{P}\right)^{-1} X_{P}^{\prime} y_{P}=\left(X_{L}^{\prime} U_{N} X_{L}\right)^{-1} X_{L}^{\prime} U_{N} y_{L}=\left(X_{L}^{\prime} X_{L}+X^{\prime}\left(U_{N}-I\right) X_{L}\right)^{-1}\left(X_{L}^{\prime} y_{L}+X^{\prime}\left(U_{N}-I\right) y_{L}\right)$,

where $U_{N}=S_{N} S_{N}^{\prime}$, the $(N T \times N T)$ block-diagonal matrix of $T(N \times N)$ matrices of ones in the diagonal and zeros elsewhere. For this exercise we assume that the loan-level estimate is unbiased:

$$
b_{L}=\left(X_{L}^{\prime} X_{L}\right)^{-1} X_{L}^{\prime} y_{L}, \quad E\left(b_{L}\right)=\beta \text {. }
$$

Only if there is no within-time cross-individual correlation in $x$ and $e$, the cross-product terms will be zero in expectations, that is $U_{N}=I$, and therefore $E\left(b_{P}\right)=E\left(b_{L}\right)=\beta$. Otherwise $E\left(b_{P}\right) \neq E\left(b_{L}\right)$, reflecting the aggregation bias 9 The same problem arises for a sub-portfolio level regressions. However, given that fewer cross-product terms appear in sub-portfolio level regressions, the bias is smaller in magnitude the less aggregated the variables are.

\footnotetext{
${ }^{9}$ Note, however, that the standard estimate of the variance of $b_{L}$ will not be unbiased, and the cluster-robust standard errors will need to be computed. See, for example, Arellano (1987).
} 
To summarize, there is no sure way to tell what level of aggregation is going to produce the best conditional projection — both in terms of bias and in terms of forecast precision. ${ }^{10}$ We have illustrated that, depending on the structure of the data, projection accuracy can be better or worse for more aggregated models compared to disaggregated models. We have also given examples in which measurement error bias is likely to arise in individual loan level regressions, while aggregation bias is likely in the aggregate regressions. Thus, what level of aggregation is the best for predicting aggregate outcomes remains an empirical question and the answer depends on the specific data set being analyzed. In the rest of the paper we present an empirical exercise for HELOCs, in which we compare out-of-sample performance of models estimated at different levels of aggregation. The optimal level of aggregation, however, may vary for different types of loans and sample characteristics.

\section{Data description}

We implement our tests of for a data set of home equity lines of credit (HELOC). As the name suggests, the HELOC is a commitment by a lender (usually a commercial bank) to lend up to a specified amount over a specified period of time called the draw period. HELOCs are collateralized by a claim to the equity in the borrowers' house. The lender is typically in a second-lien position to the lender for the first mortgage, in the case where this is a first mortgage ${ }^{11}$ Borrowers may draw down on the commitment at any time during the draw period, at which point the draw will be added to the outstanding balance. The borrower is under no obligation to draw down the full amount on the line during the draw period, or even draw anything at all. Indeed, many borrowers reputedly put HELOCs in place as insurance to smooth consumption in case of future income

\footnotetext{
${ }^{10}$ This result is also demonstrated, for in-sample fit, in Pesaran, Pierse, and Kumar (1989).

${ }^{11}$ States have different rules on whether lien status changes for home equity when a borrower refinances the first-lien mortgage. See Bond, Elul, Garyn-Tal, and Musto (2014).
} 
shocks 12 Borrowers will typically only need to make interest payments on the outstanding balance during the draw period. Interest payments are based off of a short-term benchmark interest rate such as the Prime Rate or LIBOR. After the draw period ends, further draws are not permitted and the borrower pays down the balance-either in the form of a balloon payment or over time as an amortizing loan 13

The data set is constructed from a five-percent random sample of HELOCs from the CoreLogic LP Home Equity Database. We draw only from the set of HELOCs with adjustable rates that are in the second lien position. Our resulting sample contains monthly observations on 454,724 unique HELOCs for a total of 20,757,776 observations. The sample ranges from 2002 through 2013. Delinquency is defined as the event of reaching 90-days past due. Once this event takes place the loan history in our sample is terminated, meaning that we abstract away from cures and the actual transition from default to foreclosure to loss. Thus, our measure of the delinquency or default rate is the transition rate from current into default rather than the stock of all outstanding loans in default. We adopt this convention for default because it matches up most cleanly with the probability of default construct that would go into an actual model used for stress testing and risk management.

All the specifications explored in our different risk models contain a grouping of observable economic factors. The main economic risk factors used in the analysis include the trailing 12month house price depreciation from the CoreLogic monthly house price indexes (HPI). In this paper we use house depreciation (i.e., the negative of house price appreciation) because in some specifications this transformation lends itself more easily to interpreting interaction effects between house price changes and other variables. Whenever possible we link each HELOC to a zip code level HPI. When this level of precision is not possible we revert back to the county-level HPI. If the

\footnotetext{
${ }^{12}$ See Hurst and Stafford (2004).

${ }^{13}$ See Epouhe and Hall (2015) and Johnson and Sarama (2015) for home equity default dynamics around the end of draw period.
} 
loan is situated in a county where CoreLogic has no coverage at all, we drop the history from the sample. Also included in the set of economic risk factors are the county-level unemployment rate from the BLS and a year-over-year real GDP growth series constructed from the monthly estimates provided by Macroeconomic Advisors.

To a rough approximation, the theory of default underlying the empirical specifications is that changes in economic conditions can impact a borrower's ability or willingness to stay current on the HELOC account. House prices capitalize the value of the land in a location. Thus, fluctuations in house prices can serve as summary measures for changes in local conditions. Additionally, HELOCs are collateralized by a claim to the value of the underlying house. If house prices fall enough, homeowner equity can be wiped out, reducing the incentive to repay either the first or the second lien mortgage. More directly, the local unemployment rate and economic growth measure speak to the probability that the borrower has the income or wealth to avoid default. Importantly, aggregated versions of all of these variables are used in the CCAR stress tests.

In general we adopt a parsimonious approach to model selection on the grounds that these specifications tend to do better out-of-sample. As we proceed to lower levels of aggregation, however, we include increasingly more variables as a way of giving the disaggregated models the fullest opportunity to exploit the rich data at our disposal. Thus, we include commonly used variables such as the FICO risk or credit score (FICO), the borrower debt-to-income ratio at origination (DTI), and the reported loan-to-value ratio at origination (LTV). In the loan-level model we also consider a host of other variables that speak to underwriting standards and other factors that might be correlated with unobservable borrower characteristics, such as loan age and the spread of the loan rate over the reference interest rate. We also have the ability to create an imputed current LTV by updating the loan-specific LTV at origination by its respective house price appreciation. Note that the LTV, FICO scores, and DTI have all been winsorized at the 1st and 99th percentiles of the raw empirical distribution. The summary statistics for the variables used in the risk models 
for our sample are in Table 1

Table 1: Summary Statistics

\begin{tabular}{lcccc}
\hline \hline & & & & \\
& Mean & Standard Deviation & 25th Percentile & 75th Percentile \\
\hline Loan-to-Value at origination & 37.765 & 26.073 & 15.57 & 60.11 \\
FICO at origination & 739.451 & 51.109 & 703 & 779 \\
Debt-to-Income at origination & 35.667 & 14.527 & 26.8 & 44.7 \\
Unemployment Rate, County & 6.961 & 2.884 & 4.7 & 8.9 \\
GDP growth, yearly & 1.614 & 2.072 & 1.285 & 2.856 \\
HousePrice Depreciation, yearly & -0.118 & 12.397 & -7.669 & 6.892 \\
Loan Origination, log & 11.044 & 1.008 & 10.463 & 11.575 \\
Margin Rate & 0.548 & 0.995 & 0 & .875 \\
Current Interest Rate (on HELOC) & 5.664 & 2.310 & 3.74 & 7.625 \\
Loan length, months & 222.136 & 154.819 & 0 & 360 \\
Total amount drawn, monthly & 23028.73 & 57725.14 & 0 & 17769.74 \\
\hline Observations & 20757776 & & & \\
\hline \hline
\end{tabular}

There have been some significant changes in the supply of home equity loans and lines of credit over the course of our sample period. As can be seen from Figure 1 there was a steady increase in new loan origination through the housing boom years. New originations abruptly dried up once house prices leveled off and began falling in 2006. Essentially all of our loans were originated during the 2002-2006 period. We did not include any loans that were originated prior to 2002-the starting point for our loan observations-for fear of introducing survivorship bias.

\section{Empirical analysis}

Using the data described above, we now conduct the analysis that is quite similar to stress-test modeling process of many banking institutions. We search for specifications that have good fit, include stress scenario variables, and have good out-of-sample properties. We repeat this exercise at different levels of data aggregation and investigate how well model projections are able to capture 
Figure 1: Flow and Stock of Loans in Sample

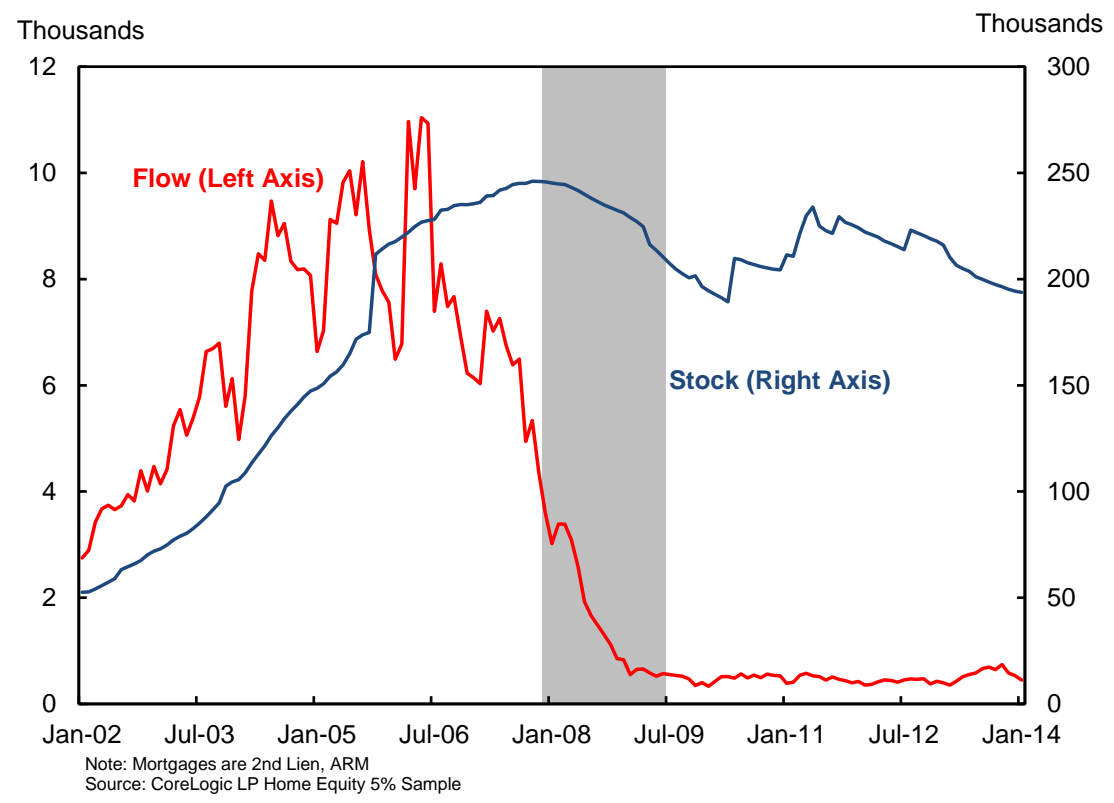

Note: Flow is the number of new HELOCs originated in a given month in our sample. Stock is the number of loans outstanding in a given month in our sample. 
turning points of HELOC delinquency rate in the sample using both in-sample and out-of-sample analysis. We also evaluate predicted delinquency rates in the 2014 supervisory severely adverse stress scenario.

\subsection{Top-down model}

We start our empirical analysis at the highest level of aggregation: the national level, which we also refer to as "portfolio", or "aggregate" level. We estimate variations of the model,

$$
y_{t}=\theta_{0}+X_{t} \beta+\varepsilon_{t}
$$

where $y_{t}=\frac{1}{N} \sum_{i=1}^{N} y_{i t}$ is the aggregate default rate from our sample of $N$ loans in month $t$, the matrix $X_{t}$ contains the averages of loan-level and macroeconomic risk covariates and their lags, $\varepsilon_{t}$ is an error term. The model in equation (1) is truly aggregated in the sense that both left and right-hand side variables are constructed as averages from the underlying loan-level data. The regressions are estimated using OLS 14

We search for the best fitting model through a large number of specifications based on all combinations of variables in Table 1 as well as their lags and interactions. We are able to narrow this large set of candidate models down to 25 models that we judged to have reasonable in-sample and outof-sample fit, and that included macroeconomic scenario variables with intuitive coefficients. For each of these specifications, we estimate the models on a full sample and on a series of 12 rolling samples. That is, starting with a sample ranging from January 2002 to July 2008, we estimate each model and then construct out-of-sample predictions from July 2008 for the next 9 quarters ${ }^{15}$ We then repeat the exercise on an estimation sample ranging from January 2002 to August 2008,

\footnotetext{
${ }^{14}$ The results do not change materially when we estimate equation 1 using a tobit specification, which limits predicted delinquency rates to non-negative space.

${ }^{15}$ We chose 9 quarters because this is the time horizon for the loss projections in the supervisory stress testing.
} 
and then perform a 9-quarter ahead forecast. We proceed in this fashion (12 times) so that the estimation sample gradually increases in size. In our longest subsample, we estimate the model up through June 2009. This set of rolling windows allows us to see how the model performs as it gradually learns about the dynamics of home equity defaults during the financial crisis and its aftermath.

We select the specification that performs well out-of-sample, on average across 12 rolling windows, in terms of the mean squared error of forecast and does not underpredict default probabilities, to be consistent with the goal of stress testing exercise to produce high losses in stress scenarios. We refer to such model as a winning specification and report all 12 regressions for this specification in Table 5 in the Appendix. We also retain information on the performance of the remaining 24 specifications.

\subsection{Intermediate levels of aggregation}

With a fully aggregated model in hand the next step is to break the delinquency rate down into subportfolios. We consider four different schemes for disaggregation: by DTI decile, LTV decile, FICO score decile, and by county: ${ }^{16}$ The estimated model is now a fixed-effect panel model,

$$
y_{j t}=\theta_{j}+X_{j t} \beta+\eta_{j t},
$$

where the $\theta_{j}$ is a subportfolio-specific fixed-effect, $y_{j t}=\frac{1}{J} \sum_{i=1}^{N_{J}} I(i \in j) y_{i t}$ is the average default rate for all loans in sub-portfolio $j$ in month $t, X_{j t}$ is the set of average values of covariates for each sub-portfolio, and $\eta_{t}$ is the error term. Each subportfolio boundary is static; these are based on the entire sample. When we aggregate to the portfolio level, each sub-portfolio, $\mathrm{j}$, is then weighted according to the number of observed loans within these boundaries.

\footnotetext{
${ }^{16}$ Only top 25 percent of counties by the share in the stock of loans as of 2005 comprise the county data set. This helps to improve the fit of the model by eliminating noise from counties with too few observations.
} 
The subportfolio approach preserves some of the potential for aggregating out the measurement error problem, while also offering flexibility to introduce more portfolio-specific information to the regressions. In the disaggregated models we make predictions of the disaggregated delinquency rates and then aggregate these predictions to compare to the aggregate outcomes. That is, when we forecast default at times $t=1, \ldots, T$ for subportfolio $j$, the MSE that we use for forecast evaluation is not the average difference between predicted and actual subportfolio default rates. Rather, it is the difference between the average aggregate default prediction and the aggregated portfolio default rate,

$$
M S E=\frac{1}{T} \sum_{t=1}^{T}\left(y_{t}-\frac{1}{J} \sum_{j=1}^{J} \hat{y}_{j t}\right)^{2}
$$

We feel that this approach more closely mimics what a bank would do when confronted with a problem of predicting total portfolio defaults or losses. If the object of interest is the portfolio default rate or loss rate, then the appropriate measure of out-of-sample fit is one where forecast error is computed at the portfolio level.

For these subportfolio models we conduct the same procedure as for aggregate model in terms of specification selection. After extensive pre-testing we end up with 22 reasonable specifications for each type of aggregation: by DTI, LTV, FICO deciles, and by county, which we estimate for the same 12 rolling windows as the aggregate model. Out of these reasonable specifications, we select winning models in the same way as we do for aggregate model, and retain information on the performance of the remaining models. Winning models for each of the four subportfolio levels and for each sample window are reported in Appendix Tables 6 through 9 . 
Figure 2: In-sample Model Predictions

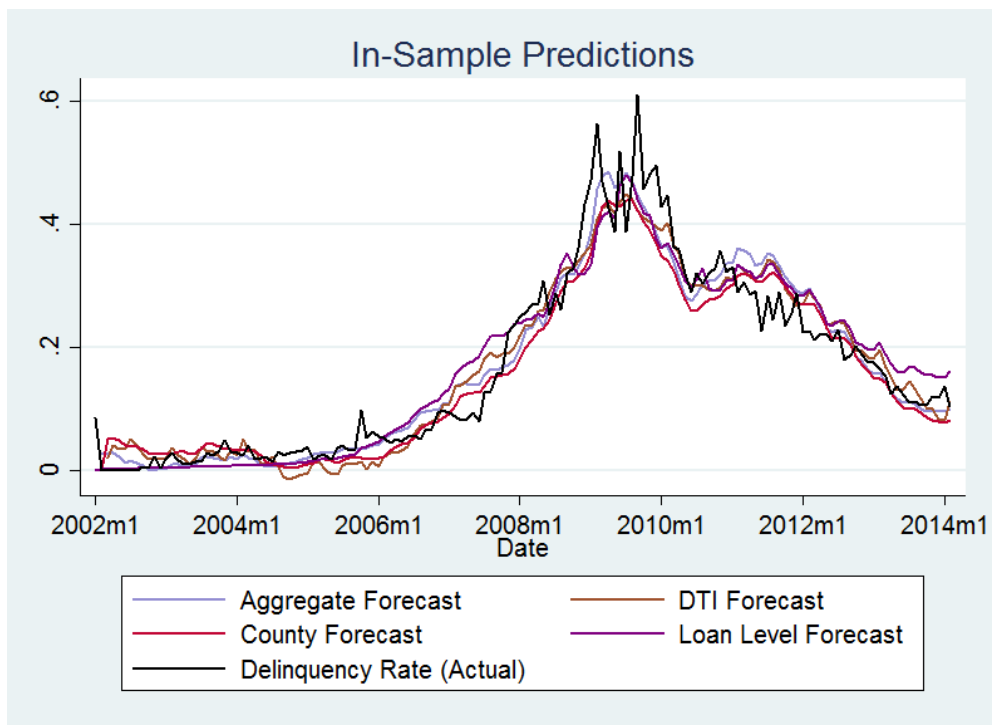

Note: Actual and predicted delinquency rates (in percent) are plotted.

Winning models for each level of aggregation estimated on the full sample are used.

\subsection{Bottom-up model}

Finally, we consider fully disaggregated loan-level models. These models are estimated as logit regressions,

$$
\operatorname{Pr}\left(y_{i t}=1\right)=\frac{\exp \left(\alpha+X_{i t} \beta\right)}{1+\exp \left(\alpha+X_{i t} \beta\right)}
$$

where $i$ is the index for individual loans or borrowers and $y_{i t}$ is a $0-1$ indicator of whether loan $i$ defaulted in month $t$. Some variables in the vector of covariates $X_{i t}$, such as unemployment rate and home price depreciation, do not vary by loan but are repeated for all loans in the same county in the same month. We cluster standard errors by county to account for resulting correlation in errors.

We select 18 reasonable models among all specification permutations, and evaluate their forecasting performance over 12 rolling regressions ending in July 2008 through June 2009. As with 
the subportfolio models, the MSE is calculated as the average deviation of the aggregated fitted default probabilities compared to the aggregate default rate,

$$
M S E=\frac{1}{T} \sum_{t=1}^{T}\left(y_{t}-\frac{1}{N} \sum_{i=1}^{N} \hat{y}_{i t}\right)^{2} .
$$

Once again we select the winning model among the 18 and report the results for all 12 rolling windows in the Appendix Table 10. We retain performance data for the remaining 17 models.

\subsection{Comparison across levels of aggregation}

The winning models for each aggregation approach are reported in Table 2. In order to not overwhelm the reader with the results, we only report the regressions that are estimated through January 2009, the middle of our rolling window set. We can see that the best specification varies with the aggregation approach, but the effects of included variables are mostly stable across specifications. We find, as one would expect, that defaults on home equity loans are more likely when unemployment rate (UR) is higher, or when the rate of home prices depreciation (HPR) is higher 17 The combination of these factors seems to lead to an additional increase in default rates. We also find in most specifications that higher debt-to-income ratios and lower FICO scores of the borrowers are associated with higher default rates.

\footnotetext{
${ }^{17}$ Note that in the regression with negative effect of the first lag of HPD (the "wrong" sign) the full effect includes additional lags or interaction terms and is overall positive, as expected.
} 
Table 2: Best Models: Regression through January 2009

\begin{tabular}{|c|c|c|c|c|c|c|}
\hline & Aggregate & DTI & LTV & FICO & County & Loan Level \\
\hline HPD, $\operatorname{lag}(1)$ & $\begin{array}{l}-0.0025 \\
(0.0039)\end{array}$ & $\begin{array}{c}0.0273^{* * *} \\
(0.0070)\end{array}$ & $\begin{array}{c}-0.0128^{* * *} \\
(0.0032)\end{array}$ & $\begin{array}{l}0.0269^{*} \\
(0.0127)\end{array}$ & $\begin{array}{c}-0.00527^{* * *} \\
(0.00198)\end{array}$ & $\begin{array}{c}0.0489^{* * *} \\
(0.0018)\end{array}$ \\
\hline $\mathrm{UR}, \operatorname{lag}(1)$ & $\begin{array}{c}0.0330^{* * *} \\
(0.0069)\end{array}$ & $\begin{array}{c}0.0127^{* *} \\
(0.0042)\end{array}$ & $\begin{array}{c}0.0059 \\
(0.0086)\end{array}$ & $\begin{array}{c}0.0201^{* * *} \\
(0.0031)\end{array}$ & $\begin{array}{c}0.02091^{* * *} \\
(0.0044)\end{array}$ & $\begin{array}{c}0.0651^{* * *} \\
(0.0150)\end{array}$ \\
\hline HPD*UR, $\operatorname{lag}(1)$ & $\begin{array}{c}0.0020^{* * *} \\
(0.0007)\end{array}$ & & $\begin{array}{c}0.0041^{* * *} \\
(0.0008)\end{array}$ & & $\begin{array}{c}0.0016^{* * *} \\
(0.0004)\end{array}$ & \\
\hline $\mathrm{HPD}, \operatorname{lag}(2)$ & & $\begin{array}{c}-0.0564^{* * *} \\
(0.0140)\end{array}$ & & $\begin{array}{l}-0.0368 \\
(0.0211)\end{array}$ & $\begin{array}{c}0.0058^{* * *} \\
(0.0021)\end{array}$ & \\
\hline $\mathrm{UR}, \operatorname{lag}(2)$ & & $\begin{array}{c}0.0200^{* * *} \\
(0.0042)\end{array}$ & & $\begin{array}{c}0.0258^{* * *} \\
(0.0054)\end{array}$ & $\begin{array}{c}0.0049 \\
(0.0045)\end{array}$ & \\
\hline HPD*UR, $\operatorname{lag}(2)$ & & & & & $\begin{array}{l}-0.0003 \\
(0.0004)\end{array}$ & \\
\hline $\operatorname{HPD}, \operatorname{lag}(3)$ & & $\begin{array}{c}0.0350^{* * *} \\
(0.0078)\end{array}$ & & $\begin{array}{c}0.0194 \\
(0.0107)\end{array}$ & & \\
\hline DTI, $\operatorname{lag}(1)$ & $\begin{array}{c}0.0109^{* * *} \\
(0.0011)\end{array}$ & $\begin{array}{c}-0.0102^{* *} \\
(0.0044)\end{array}$ & $\begin{array}{c}0.0001 \\
(0.0021)\end{array}$ & $\begin{array}{c}0.0208^{* * *} \\
(0.0059)\end{array}$ & $\begin{array}{c}0.00428^{* * *} \\
(0.00054)\end{array}$ & $\begin{array}{c}-0.0031^{* * *} \\
(0.0010)\end{array}$ \\
\hline FICO, $\operatorname{lag}(1)$ & & $\begin{array}{c}0.0073^{* * *} \\
(0.0019)\end{array}$ & & $\begin{array}{c}-0.0122^{* *} \\
(0.0051)\end{array}$ & & spline \\
\hline LTV, lag(1) & $\begin{array}{l}0.0049^{* *} \\
(0.0020)\end{array}$ & & & & & spline (imputed) \\
\hline Loan Amount, lag(1) & & $\begin{array}{c}0.1514^{* * *} \\
(0.0385)\end{array}$ & & $\begin{array}{l}-0.3764 \\
(0.2264)\end{array}$ & & \\
\hline Constant & $\begin{array}{c}-0.5959^{* * *} \\
(0.1007)\end{array}$ & & & & & $\begin{array}{c}-8.4449^{* * *} \\
(1.6041)\end{array}$ \\
\hline Additional Loan Characteristics & No & No & No & No & No & Yes \\
\hline Fixed Effects & No & Yes & Yes & Yes & Yes & No \\
\hline Observations & 83 & 810 & 830 & 810 & 24854 & 6208287 \\
\hline Adjusted $R^{2}$ & 0.9300 & 0.8557 & 0.6387 & 0.6363 & 0.3655 & 0.1961 \\
\hline MSE & 0.0046 & 0.0070 & 0.0135 & 0.0046 & 0.0041 & 0.0617 \\
\hline Loss & 0.9766 & 0.9832 & 1.0576 & 1.0346 & 1.0293 & 1.2754 \\
\hline
\end{tabular}




\subsection{Out-of-sample tests}

Before turning to the out-of-sample results we first examine the in-sample performance of our models when estimated over the full sample of data. These plots of in-sample fitted default probabilities can be found in Figure 2. The models profiled here are actually selected on the basis of out-ofsample performance. However, it is useful to demonstrate from the beginning that all aggregation levels demonstrate a similar capability of fitting the data in-sample. All four model categories (loan level, county level, segment level, and aggregate) can roughly match the timing of the turning point in delinquency series. None of the four models is quite able to match the peak in defaults observed. We see from Table 2 that the county-level model model performs slightly better than the others in terms of MSE. But, from a visual perspective at least, there is little a priori reason to expect one particular aggregation level to dominate in the out-of-sample predictions.

With this starting point we can proceed to the out-of-sample comparisons. Figure 3 shows the performance of the out-of-sample forecast of our winning models. The top panel shows the forecasts of the regressions with the estimation window through July 2008, the middle panel through January 2009 (regressions reported in Table 2), the bottom panel through June 2009. We can compare the forecasts resulting from each approach with the data. We find that the loan-level forecast consistently under-predicts default frequency in the aggregate, while aggregate forecasts over-predicts default frequency in the beginning of our rolling window. We also observe that aggregation by LTV buckets produces quite poor results, while aggregation by DTI and FICO buckets produce good results that are similar to each other. DTI and FICO approaches, however, tend to over-predict default frequencies in the second half of our rolling forecast window. Countylevel aggregation models produce forecasts that are quite accurate and stable, with the exception of the second half of the forecast horizon in the regressions that end before the crisis (top panel).

We can formalize these observations by comparing MSEs of all reasonable models we estimated across all 12 rolling forecast windows for each aggregation approach. Table 3 presents summary 
Figure 3: Out-of-Sample Forecast

\section{Regression through July 2008}
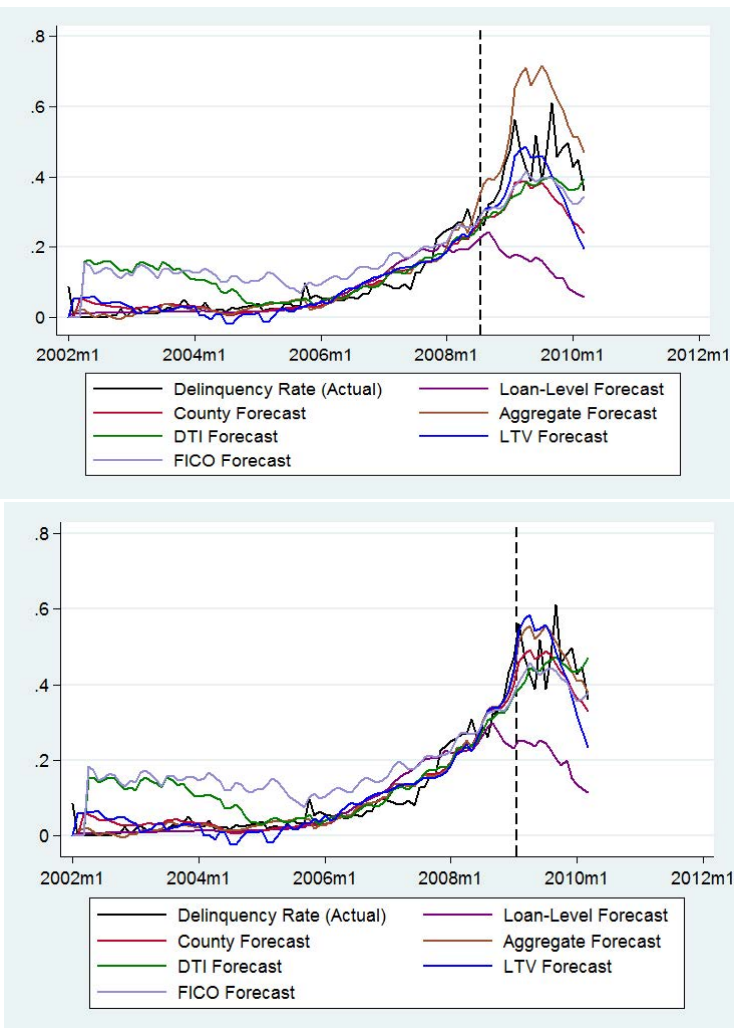

Regression through June 2009

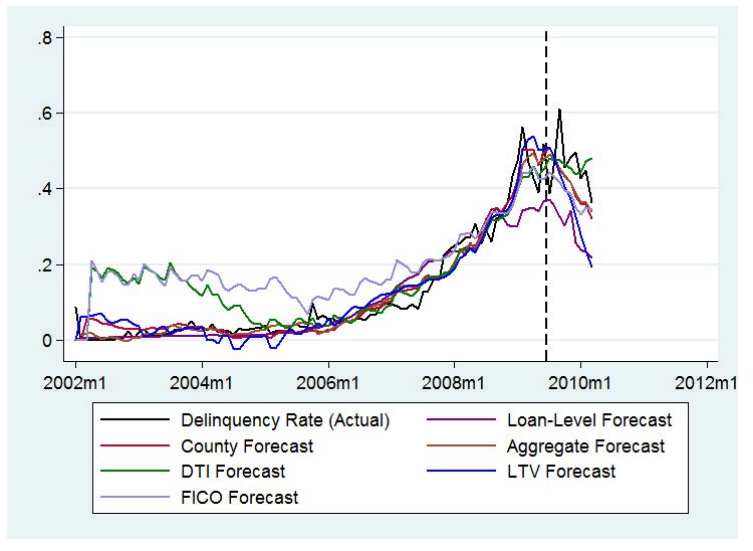

Note: dashed line indicates the last month of estimation sample. Actual and fitted delinquency 3 ates (in percent) are plotted. 
statistics for all resulting MSEs, by aggregation approach, as well as average MSE for each winning model across 12 rolling forecast windows. We find that on average, county-level models have the smallest forecast errors, which also don't vary much across specifications. This is consistent with our expectations, because macroeconomic information that enters the regressions varies by county and is therefore fully explored in these regressions, while not generating measurement errors as in loan-level regressions. While the MSE of the winning model of the portfolio-level approach is smaller than that of the county-level, we can see that there is high variation in the precision of the aggregate model projection resulting from small perturbations in model specification.

Table 3: MSE Summary: Based on 9 quarter forecast

\begin{tabular}{lcccccc}
\hline \hline & & & & & & \\
& Aggregate & FICO & LTV & DTI & County & Loan Level \\
\hline Mean & 0.0325 & 0.0416 & 0.0417 & 0.0356 & 0.0158 & 0.0845 \\
Std Dev & 0.0478 & 0.0759 & 0.0784 & 0.0605 & 0.0141 & 0.0130 \\
Min. & 0.0035 & 0.0035 & 0.0038 & 0.0053 & 0.0031 & 0.0180 \\
Max. & 0.2683 & 0.6892 & 0.695 & 0.4984 & 0.0709 & 0.1153 \\
\hline Winning Model & 0.0064 & 0.0073 & 0.0197 & 0.0221 & 0.0080 & 0.0590 \\
(average MSE) & & & & & & \\
\hline \hline
\end{tabular}

All summary statistics refer to MSEs defined in equation 5 from all models deemed reasonable across all 12 rolling windows. For the winning model the average MSE is computed across 12 rolling windows. See Appendix for winning model regression.

In the stress testing exercise accuracy of projection is the primary, but not the only, goal. Given model uncertainty, however, it is also important that the errors of the forecast are more likely to be on the conservative side. In particular, this would be true from a financial stability perspective where underpredictions may be viewed more seriously than overpredictions. Thus, we construct a "conservative loss" measure

$$
C L=\frac{1}{T} \sum_{t=1}^{T} \exp \left(y_{t}-\hat{y}_{t}\right),
$$

where $\hat{y}_{t}$ for disaggregated models is computed as average projections. This measure is equal to 
1 if there is no error, is below 1 if the error is on the side of over-predicting default frequency, and is above 1 if the model is under-predicting defaults. Summary statistics for this loss measure are presented for all reasonable models across all 12 forecast windows for each of our aggregation approaches in Table 4. We find that the aggregate model produces more conservative forecasts on average, as we saw in Figure 1, but that the loss measure varies substantially across specifications. The sub-portfolio models all have similar loss measures on average with county-level loss measures being the most stable across regression specifications. The loan-level models have the least variation across forecast windows according to the loss measure. However, this low variation in the loss measure comes at the expense of a very high mean loss. This appears to be one of the most robust results in the out-of sample analysis. Across all forecast windows and loss functions, the loan level models have a strong tendency to underpredict defaults.

Table 4: Loss Summary

\begin{tabular}{lcccccc}
\hline \hline & & & & & & \\
& Aggregate & FICO & LTV & DTI & County & Loan Level \\
\hline Mean & 0.9655 & 1.020 & 1.108 & 1.0721 & 1.0541 & 1.3178 \\
Std Dev & 0.1598 & 0.1813 & 0.187 & 0.1795 & 0.1015 & 0.0355 \\
Min. & 0.6709 & 0.4922 & 0.6927 & 0.6171 & 0.8463 & 1.1288 \\
Max. & 1.6425 & 1.7003 & 2.282 & 1.9814 & 1.2901 & 1.3978 \\
\hline Winning Model & 0.9837 & 1.0412 & 1.0750 & 1.1192 & 1.0478 & 1.2553 \\
(average CL) & & & & & & \\
\hline \hline
\end{tabular}

All summary statistics refer to CL defined in equation 6 from all models deemed reasonable across all 12 rolling windows. For the winning model the average CL is computed across 12 rolling windows. See Appendix for winning model regression.

\subsection{Stress test projections}

As a final exercise we compare projections of the different champion models using the macroeconomic scenarios deployed in the CCAR 2014 stress tests. The Federal Reserve releases three different economic scenarios that financial institutions use to stress their balance sheet exposures. 
Figure 4: CCAR 2014 Stress Scenarios
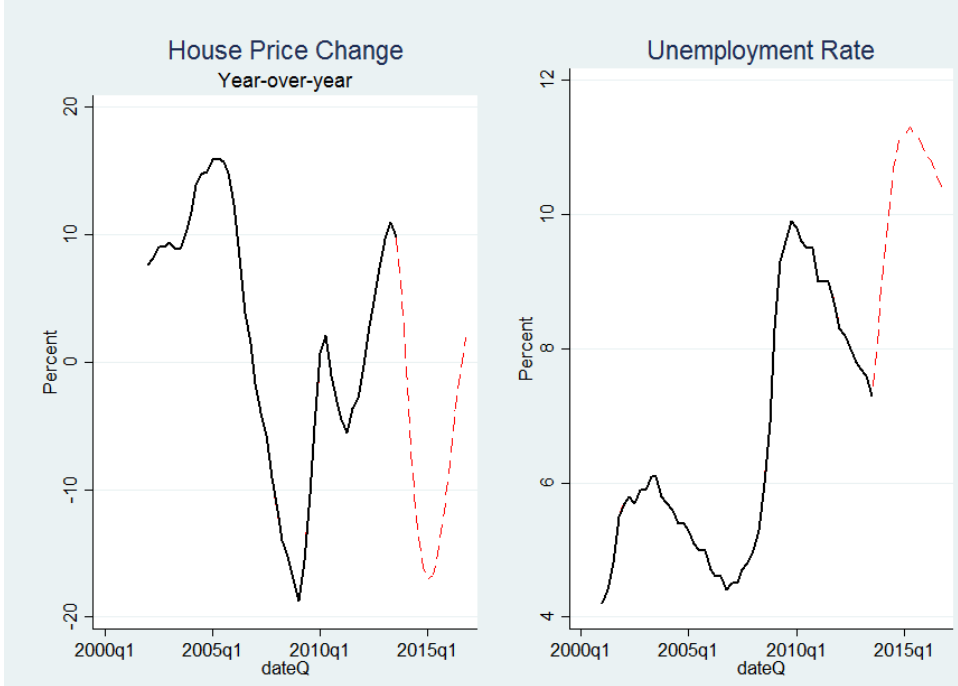

Source: Federal Reserve Board.

We focus here on the 2014 "severely adverse" scenario which features a deep recession much like the one experienced by the U.S. starting in 2007. The scenario consists of a nine-quarter path for a large set of variables measuring economic activity ${ }^{18}$ In Figure 4 we plot the paths for the key variables that go into the home equity default models. House prices were assumed to fall through the scenario 10 percent year-over-year rates before leveling off at the end of the scenario horizon in 2016. The unemployment shock was particularly severe in the CCAR 2014 exercise, with the rate climbing to about 11 percent at the peak.

In the specification searches described earlier, we allow the models at each aggregation level to make use of the real GDP growth measure, house prices changes, and unemployment. However, none of the champion specifications at any aggregation level selected GDP growth. Similarly, the current interest rate on the home equity line of credit was among the set of variables available for the loan-level specifications. All of the home equity lines in our sample have payments based on

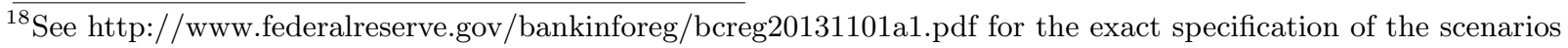
and variables included.
} 
short-term interest rates that change over time (i.e., adjustable-rate lines of credit), and proxies for short-term rates are included in the macroeconomic scenarios. But again, this variable was not selected in the champion loan-level model. Thus, the stress projections from this set of models are wholly determined by the assumed scenarios for house prices and the unemployment rate.

For the aggregate model and most of the segmented models, it is fairly routine to simulate out projected default rates. The first thing we do is convert the monthly data of our default models into the quarterly frequency of the CCAR scenarios. We do this by keeping the last monthlyobservation of each loan in every quarter. Next, the champion model specifications listed in Table 2 are estimated using data through the third quarter of 2013, as the fourth quarter of 2013 is the start of the CCAR 2014 exercise. The loans in the portfolio and their relevant characteristics at origination are held constant as of this date. We then use the estimated model coefficients and the assumed paths of house prices and unemployment to project out aggregate and segmented portfolio default rates. In the case of the segmented portfolios, these default projections are then aggregated to produce projected aggregate default rates under the CCAR scenarios. In the case of the loanlevel and the county-level models, we must perform an extra step to map the aggregate path for house prices and unemployment down to the local level. We do this using a simple regression model. Specifically, we model the relationships between aggregate house price appreciation (HPA) and unemployment (UR) and their zip-code and county-level counterparts, respectively, as follows:

$$
\begin{aligned}
& H P A_{k t}=\alpha_{j}+\beta_{j} H P A_{t}^{a g g}+\epsilon_{k t}, \\
& U R_{j t}=\theta_{j}+\gamma_{j} U R_{t}^{a g g}+\eta_{j t},
\end{aligned}
$$

for each zip code $k$ or county $j$ in our sample. With the estimated coefficients from these models in hand, we simulate out county-level variables, as required by the champion county-level and loan-level models. 
Figure 5: Stress Scenario Predictions

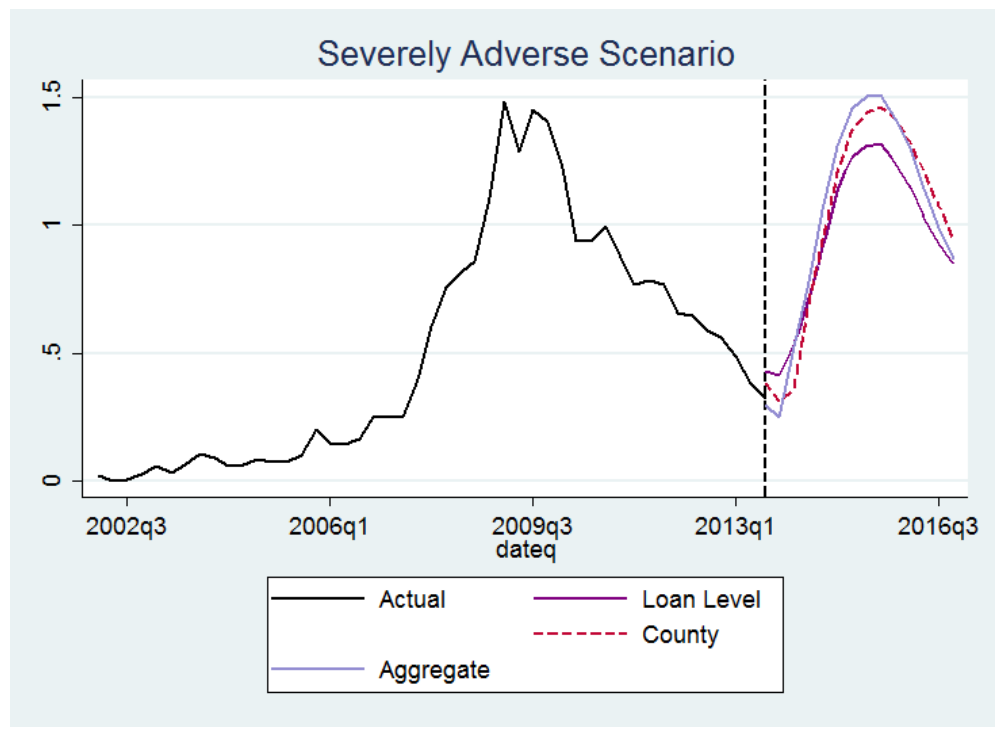

Notes: Projections are constructed from winning models for each level of aggregation estimated on the sample ending in 2013:Q3.

The results from the stress test simulation are in Figure 5. In this chart we follow the CCAR stress test convention and report default rates at the quarterly frequency. Turning to results, we note the broad contours of the aggregate, county-level, and loan-level projections are quite similar. This is not surprising given that these same macro risk factors enter into these models, just at different levels of aggregation. Interestingly, we still see that the loan-level model has slightly less sensitivity to shocks than the aggregate and the county-level models. Of course, we cannot say for sure whether this is a virtue or a shortcoming. We are comparing default projections in response to hypothetical shocks that have not actually occurred. Even so, the attenuation that we see in the risk factor sensitivities in the loan-level model still appears to be present in these simulations that make use of the full sample of available data. 


\section{Conclusion}

In this paper we compare risk models with different levels of aggregation: from loan-level to aggregate portfolio-level models. We consider hybrid approaches where we model default probabilities for different segments of a portfolio, such as buckets of debt-to-income ratios, loan-to-value ratios, FICO risk scores, and with loans aggregated by county. We conduct our tests on a large portfolio of home equity loans and lines of credit. We evaluate models' performance specifically for their suitability for CCAR stress-testing exercises, which are based on scenario analysis.

In our sample of home equity lines and loans, neither loan-level models nor portfolio-level models are ideal for the specific exercise of regulatory stress testing we have in mind. In the CCAR stress testing exercises, scenario drivers are supplied at national level, with some variables disaggregated by private data vendors by geographical regions such as state, metropolitan area, or county. Default and loss data, however, are frequently available for the banking institution at loan level. The question that arises is whether it is better to aggregate data first and then estimate the risk model, to estimate loan level model and then to aggregate projections, or to estimate some intermediate aggregation level model. We demonstrate that, in principle, loan-level models may be subject to measurement errors that arise from the explanatory variables that are not available at the loan

level, while aggregate models may be subject to aggregation bias. In our empirical exercise we find that this tension is best resolved at the intermediate level of aggregation. In particular, county-level regressions, where macroeconomic variables at county level are used, appear to perform best for the purpose of stress testing. Other hybrid approaches also perform better than either loan-level model or aggregate model.

We measure model performance using criteria appropriate for the stress testing exercise. The MSE criterion puts equal weight on positive and negative forecast errors. Policymakers and bank supervisors, however, are often thought to have preferences that put more weight on downside risks than upside risks. For this reason, we also employ a "conservative loss" measure which punishes 
model underpredictions. In this context, loan-level models appear to perform particularly poorly, given their persistent underprediction of home equity default rates. While aggregate models are quite conservative on average, their predictions are not robust to model specification and can at times produce very low default rates.

To be clear, our goal is not to recommend one specific level of aggregation for loss risk modeling. The purpose of our exercise is to illustrate, using an example of home equity lines of credit, that aggregation level matters. In some cases, intermediate levels of aggregation might be a best approach to modeling default probabilities or loss rates on banks' loan portfolios. We also provide an econometric argument that shows why this might be the case. Our hope is that researchers, regulators, and practitioners alike devote due attention to the implications of the aggregation level of models used for stress testing. Availability of the loan-level data allows institutions to consider aggregation level as a key factor in model design. 


\section{References}

Arellano, M. (1987): "Computing Robust Standard Errors for Within-Group Estimators," Oxford Bulletin of Economics and Statistics, 49, 431-434.

Bond, P., R. Elul, S. Garyn-Tal, and D. K. Musto (2014): "Does Junior Inherit? Refinancing and Blocking Power of Second Mortgages," Federal Reserve Bank of Philadelphia working paper No. 13-3.

Epouhe, O., And A. Hall (2015): "Payment Shock in HELOCS at the End of the Draw Period," Federal Reserve Bank of Philadelphia Working Paper.

Frame, W. S., K. Gerardi, and P. Willen (2015): "The Failure of Supervisory Stress Testing:

Fannie Mae, Freddie Mac, and OFHEO," Federal Reserve Bank of Atlanta working paper.

Gerardi, K., K. Herkenhoff, L. Ohanian, and P. Willen (2013): "Unemployment, Negative Equity, and Strategic Default," Federal Reserve Bank of Atlanta Working Paper.

Granger, C. (1980): "Long memory relationships and the aggregation of dynamic models," Journal of Econometrics, 14, 227-238.

Grunfeld, Y., And Z. Griliches (1960): "Is Aggregation Necessarily Bad?," Review of Economics and Statistics, 42(1), 1-13.

Gyourko, J., And J. Tracy (2013): "Unemployment and Unobserved Credit Risk in the FHA Single Family Mortgage Insurance Fund," NBER Working Paper No 18880.

Hirtle, B., A. Kovner, J. Vickery, and M. Bhanot (2014): “Assessing Financial Stability: The Capital and Loss Assessment under Stress Scenarios (CLASS) Model," Federal Reserve Bank of New York Staff Report No. 663. 
Hurst, E., And F. Stafford (2004): "Home is Where the Equity Is: Liquidity Constraints, Refinancing, and Consumption," Journal of Money, Credit, and Banking, 36(6), 985-1014.

Johnson, K., and R. Sarama (2015): "End of the Line: Behavior of Credit-Constrained HELOC Borrowers," Federal Reserve Board of Governors Working Paper.

Pesaran, M., R. Pierse, and M. Kumar (1989): "Econometric Analysis of Aggregation in the Context of Linear Prediction Models," Econometrica, 57(4), 861-888.

TheIL, H. (1954): Linear Aggregation of Economic Relations. Amsterdam.

\section{Appendix}


Table 5: Portfolio Level

\begin{tabular}{|c|c|c|c|c|c|c|c|c|c|c|c|c|}
\hline & (1) & $(2)$ & (3) & (4) & $(5)$ & $(6)$ & $(7)$ & $(8)$ & (9) & $(10)$ & (11) & $(12)$ \\
\hline DTI, lag(1) & $\begin{array}{c}0.0118^{* * *} \\
(0.0013)\end{array}$ & $\begin{array}{c}0.0113^{* * * *} \\
(0.0012)\end{array}$ & $\begin{array}{c}0.0106^{* * *} \\
(0.0012)\end{array}$ & $\begin{array}{c}0.0106^{* * *} \\
(0.0012)\end{array}$ & $\begin{array}{c}0.0107^{* * *} \\
(0.0011)\end{array}$ & $\begin{array}{c}0.0108^{* * *} \\
(0.0011)\end{array}$ & $\begin{array}{c}0.0109^{* * *} \\
(0.0011)\end{array}$ & $\begin{array}{c}0.0110^{* * * *} \\
(0.0011)\end{array}$ & $\begin{array}{c}0.0109^{* * *} \\
(0.0011)\end{array}$ & $\begin{array}{c}0.0110^{* * *} \\
(0.0011)\end{array}$ & $\begin{array}{c}0.0112^{* * *} \\
(0.0012)\end{array}$ & $\begin{array}{c}0.0112^{* * *} \\
(0.0012)\end{array}$ \\
\hline $\mathrm{HPD}, \operatorname{lag}(1)$ & $\begin{array}{l}-0.0084 \\
(0.0064)\end{array}$ & $\begin{array}{l}-0.0044 \\
(0.0055)\end{array}$ & $\begin{array}{c}0.0015 \\
(0.0053)\end{array}$ & $\begin{array}{c}0.0013 \\
(0.0043)\end{array}$ & $\begin{array}{c}0.0009 \\
(0.0040)\end{array}$ & $\begin{array}{l}-0.0000 \\
(0.0038)\end{array}$ & $\begin{array}{c}-0.0025 \\
(0.0039)\end{array}$ & $\begin{array}{l}-0.0040 \\
(0.0032)\end{array}$ & $\begin{array}{c}-0.0048^{* *} \\
(0.0023)\end{array}$ & $\begin{array}{l}-0.0020 \\
(0.0029)\end{array}$ & $\begin{array}{c}0.0002 \\
(0.0028)\end{array}$ & $\begin{array}{c}0.0011 \\
(0.0026)\end{array}$ \\
\hline UR, lag(1) & $\begin{array}{c}0.0447^{* * *} \\
(0.0114)\end{array}$ & $\begin{array}{c}0.0374^{* * *} \\
(0.0097)\end{array}$ & $\begin{array}{c}0.0275^{* * * *} \\
(0.0095)\end{array}$ & $\begin{array}{c}0.0278^{* * *} \\
(0.0079)\end{array}$ & $\begin{array}{c}0.0284^{* * *} \\
(0.0074)\end{array}$ & $\begin{array}{c}0.0298^{* * *} \\
(0.0070)\end{array}$ & $\begin{array}{c}0.0330^{* * *} \\
(0.0069)\end{array}$ & $\begin{array}{c}0.0347^{* * *} \\
(0.0061)\end{array}$ & $\begin{array}{c}0.0354^{* * * *} \\
(0.0055)\end{array}$ & $\begin{array}{c}0.0325^{* * *} \\
(0.0059)\end{array}$ & $\begin{array}{c}0.0296^{* * *} \\
(0.0061)\end{array}$ & $\begin{array}{c}0.0271^{* * *} \\
(0.0061)\end{array}$ \\
\hline HPD*UR, $\operatorname{lag}(1)$ & $\begin{array}{c}0.0032^{* *} \\
(0.0013)\end{array}$ & $\begin{array}{c}0.0024^{* *} \\
(0.0011)\end{array}$ & $\begin{array}{c}0.0012 \\
(0.0010)\end{array}$ & $\begin{array}{c}0.0012 \\
(0.0008)\end{array}$ & $\begin{array}{l}0.0013^{*} \\
(0.0007)\end{array}$ & $\begin{array}{c}0.0015^{* *} \\
(0.0007)\end{array}$ & $\begin{array}{c}0.0020^{* * *} \\
(0.0007)\end{array}$ & $\begin{array}{c}0.0023^{* * *} \\
(0.0006)\end{array}$ & $\begin{array}{c}0.0024^{* * *} \\
(0.0004)\end{array}$ & $\begin{array}{c}0.0019^{* * *} \\
(0.0005)\end{array}$ & $\begin{array}{c}0.0015^{* * *} \\
(0.0005)\end{array}$ & $\begin{array}{c}0.0014^{* * *} \\
(0.0005)\end{array}$ \\
\hline LTV, lag(1) & $\begin{array}{c}0.0058^{* * *} \\
(0.0021) \\
\end{array}$ & $\begin{array}{c}0.0052^{* *} \\
(0.0021) \\
\end{array}$ & $\begin{array}{c}0.0044^{* *} \\
(0.0021) \\
\end{array}$ & $\begin{array}{c}0.0045^{* *} \\
(0.0021) \\
\end{array}$ & $\begin{array}{c}0.0045^{* *} \\
(0.0021) \\
\end{array}$ & $\begin{array}{c}0.0047^{* *} \\
(0.0021) \\
\end{array}$ & $\begin{array}{c}0.0049^{* *} \\
(0.0020) \\
\end{array}$ & $\begin{array}{c}0.0051^{* *} \\
(0.0020) \\
\end{array}$ & $\begin{array}{c}0.0051^{* *} \\
(0.0020) \\
\end{array}$ & $\begin{array}{c}0.0051^{* *} \\
(0.0021)\end{array}$ & $\begin{array}{c}0.0053^{* *} \\
(0.0022) \\
\end{array}$ & $\begin{array}{c}0.0056^{* *} \\
(0.0023) \\
\end{array}$ \\
\hline Observations & 77 & 78 & 79 & 80 & 81 & 82 & 83 & 84 & 85 & 86 & 87 & 88 \\
\hline Adjusted $R^{2}$ & 0.8876 & 0.8961 & 0.8947 & 0.9060 & 0.9153 & 0.9237 & 0.9300 & 0.9391 & 0.9500 & 0.9489 & 0.9447 & 0.9425 \\
\hline MSE & 0.0196 & 0.0069 & 0.0045 & 0.0043 & 0.0039 & 0.0037 & 0.0046 & 0.00671 & 0.0080 & 0.0056 & 0.0044 & 0.0045 \\
\hline Loss & 0.8948 & 0.9513 & 1.0413 & 1.0382 & 1.0312 & 1.0134 & 0.9766 & 0.9542 & 0.9433 & 0.9665 & 0.989 & 1.004 \\
\hline
\end{tabular}

v
Variables are based on the mean value, by date. 
Table 6: DTI Level

\begin{tabular}{|c|c|c|c|c|c|c|c|c|c|c|c|c|}
\hline & (1) & $(2)$ & $(3)$ & $(4)$ & $(5)$ & $(6)$ & $(7)$ & $(8)$ & $(9)$ & (10) & (11) & (12) \\
\hline FICO, lag(1) & $\begin{array}{c}0.0069^{* * *} \\
(0.0016)\end{array}$ & $\begin{array}{c}0.0069^{* * *} \\
(0.0016)\end{array}$ & $\begin{array}{c}0.0066^{* * *} \\
(0.0016)\end{array}$ & $\begin{array}{c}0.0067^{* * *} \\
(0.0017)\end{array}$ & $\begin{array}{c}0.0067^{* * *} \\
(0.0017)\end{array}$ & $\begin{array}{c}0.0069^{* * *} \\
(0.0018)\end{array}$ & $\begin{array}{c}0.0073^{* * *} \\
(0.0019)\end{array}$ & $\begin{array}{c}0.0076^{* * *} \\
(0.0021)\end{array}$ & $\begin{array}{c}0.0079^{* * *} \\
(0.0021)\end{array}$ & $\begin{array}{c}0.0082^{* * *} \\
(0.0020)\end{array}$ & $\begin{array}{c}0.0085^{* * *} \\
(0.0018)\end{array}$ & $\begin{array}{c}0.0087^{* * *} \\
(0.0017)\end{array}$ \\
\hline DTI, $\operatorname{lag}(1)$ & $\begin{array}{c}-0.0109^{* *} \\
(0.0037)\end{array}$ & $\begin{array}{c}-0.0107^{* *} \\
(0.0038)\end{array}$ & $\begin{array}{c}-0.0102^{* *} \\
(0.0038)\end{array}$ & $\begin{array}{c}-0.0098^{* *} \\
(0.0040)\end{array}$ & $\begin{array}{c}-0.0095^{* *} \\
(0.0042)\end{array}$ & $\begin{array}{c}-0.0096^{*} \\
(0.0044)\end{array}$ & $\begin{array}{c}-0.0102^{* *} \\
(0.0044)\end{array}$ & $\begin{array}{c}-0.0101^{*} \\
(0.0048)\end{array}$ & $\begin{array}{c}-0.0098^{*} \\
(0.0049)\end{array}$ & $\begin{array}{c}-0.0105^{*} \\
(0.0048)\end{array}$ & $\begin{array}{c}-0.0119^{* *} \\
(0.0044)\end{array}$ & $\begin{array}{c}-0.0129^{* *} \\
(0.0040)\end{array}$ \\
\hline HPD, $\operatorname{lag}(1)$ & $\begin{array}{c}0.0308^{* * *} \\
(0.0080)\end{array}$ & $\begin{array}{c}0.0292^{* * *} \\
(0.0074)\end{array}$ & $\begin{array}{c}0.0282^{* * *} \\
(0.0075)\end{array}$ & $\begin{array}{c}0.0274^{* * *} \\
(0.0072)\end{array}$ & $\begin{array}{c}0.0283^{* * *} \\
(0.0073)\end{array}$ & $\begin{array}{c}0.0267^{* * *} \\
(0.0071)\end{array}$ & $\begin{array}{c}0.0273^{* * *} \\
(0.0070)\end{array}$ & $\begin{array}{c}0.0361^{* * *} \\
(0.0083)\end{array}$ & $\begin{array}{c}0.0311^{* * *} \\
(0.0073)\end{array}$ & $\begin{array}{c}0.0335^{* * *} \\
(0.0068)\end{array}$ & $\begin{array}{c}0.0301^{* * *} \\
(0.0066)\end{array}$ & $\begin{array}{c}0.0313^{* * *} \\
(0.0067)\end{array}$ \\
\hline $\mathrm{UR}, \operatorname{lag}(1)$ & $\begin{array}{c}0.0068 \\
(0.0053)\end{array}$ & $\begin{array}{c}0.0086 \\
(0.0048)\end{array}$ & $\begin{array}{c}0.0066 \\
(0.0043)\end{array}$ & $\begin{array}{c}0.0073 \\
(0.0042)\end{array}$ & $\begin{array}{c}0.0069 \\
(0.0043)\end{array}$ & $\begin{array}{l}0.0085^{*} \\
(0.0044)\end{array}$ & $\begin{array}{c}0.0127^{* *} \\
(0.0042)\end{array}$ & $\begin{array}{c}0.0182^{* * *} \\
(0.0043)\end{array}$ & $\begin{array}{c}0.0362^{* * *} \\
(0.0057)\end{array}$ & $\begin{array}{c}0.0348^{* * *} \\
(0.0062)\end{array}$ & $\begin{array}{c}0.0361^{* * *} \\
(0.0064)\end{array}$ & $\begin{array}{c}0.0415^{* * *} \\
(0.0060)\end{array}$ \\
\hline $\operatorname{HPD}, \operatorname{lag}(2)$ & $\begin{array}{c}-0.0596^{* * *} \\
(0.0152)\end{array}$ & $\begin{array}{c}-0.0571^{* * *} \\
(0.0142)\end{array}$ & $\begin{array}{c}-0.0538^{* * *} \\
(0.0143)\end{array}$ & $\begin{array}{c}-0.0528^{* * *} \\
(0.0139)\end{array}$ & $\begin{array}{c}-0.0550^{* * *} \\
(0.0142)\end{array}$ & $\begin{array}{c}-0.0532^{* * *} \\
(0.0140)\end{array}$ & $\begin{array}{c}-0.0564^{* * *} \\
(0.0140)\end{array}$ & $\begin{array}{c}-0.0728^{* * *} \\
(0.0162)\end{array}$ & $\begin{array}{c}-0.0564^{* * *} \\
(0.0136)\end{array}$ & $\begin{array}{c}-0.0622^{* * *} \\
(0.0132)\end{array}$ & $\begin{array}{c}-0.0554^{* * *} \\
(0.0127)\end{array}$ & $\begin{array}{c}-0.0565^{* * *} \\
(0.0128)\end{array}$ \\
\hline $\mathrm{UR}, \operatorname{lag}(2)$ & $\begin{array}{c}0.0165^{* * *} \\
(0.0039)\end{array}$ & $\begin{array}{c}0.0160^{* * *} \\
(0.0040)\end{array}$ & $\begin{array}{c}0.0147^{* * *} \\
(0.0041)\end{array}$ & $\begin{array}{c}0.0162^{* * *} \\
(0.0041)\end{array}$ & $\begin{array}{c}0.0177^{* * *} \\
(0.0042)\end{array}$ & $\begin{array}{c}0.0187^{* * *} \\
(0.0042)\end{array}$ & $\begin{array}{c}0.0200^{* * *} \\
(0.0042)\end{array}$ & $\begin{array}{c}0.0212^{* * *} \\
(0.0044)\end{array}$ & $\begin{array}{c}0.0161^{* * *} \\
(0.0047)\end{array}$ & $\begin{array}{c}0.0146^{* *} \\
(0.0046)\end{array}$ & $\begin{array}{c}0.0059 \\
(0.0041)\end{array}$ & $\begin{array}{l}-0.0040 \\
(0.0033)\end{array}$ \\
\hline $\mathrm{HPD}, \operatorname{lag}(3)$ & $\begin{array}{c}0.0344^{* * *} \\
(0.0079)\end{array}$ & $\begin{array}{c}0.0336^{* * *} \\
(0.0075)\end{array}$ & $\begin{array}{c}0.0312^{* * *} \\
(0.0076)\end{array}$ & $\begin{array}{c}0.0311^{* * *} \\
(0.0075)\end{array}$ & $\begin{array}{c}0.0325^{* * *} \\
(0.0077)\end{array}$ & $\begin{array}{c}0.0323^{* * *} \\
(0.0077)\end{array}$ & $\begin{array}{c}0.0350^{* * *} \\
(0.0078)\end{array}$ & $\begin{array}{c}0.0424^{* * *} \\
(0.0087)\end{array}$ & $\begin{array}{c}0.0305^{* * *} \\
(0.0071)\end{array}$ & $\begin{array}{c}0.0340^{* * *} \\
(0.0072)\end{array}$ & $\begin{array}{c}0.0307^{* * *} \\
(0.0070)\end{array}$ & $\begin{array}{c}0.0307^{* * *} \\
(0.0069)\end{array}$ \\
\hline Loan Amt, lag(1) & $\begin{array}{c}0.1226^{* *} \\
(0.0451)\end{array}$ & $\begin{array}{c}0.1283^{* *} \\
(0.0446)\end{array}$ & $\begin{array}{c}0.1194^{* *} \\
(0.0424)\end{array}$ & $\begin{array}{c}0.1263^{* *} \\
(0.0411)\end{array}$ & $\begin{array}{c}0.1297^{* *} \\
(0.0404)\end{array}$ & $\begin{array}{c}0.1373^{* * *} \\
(0.0398)\end{array}$ & $\begin{array}{c}0.1514^{* * *} \\
(0.0385)\end{array}$ & $\begin{array}{c}0.1613^{* * *} \\
(0.0400)\end{array}$ & $\begin{array}{c}0.1822^{* * *} \\
(0.0394)\end{array}$ & $\begin{array}{c}0.1690^{* * *} \\
(0.0381)\end{array}$ & $\begin{array}{c}0.1435^{* * *} \\
(0.0361)\end{array}$ & $\begin{array}{c}0.1233^{* * *} \\
(0.0346)\end{array}$ \\
\hline Observations & 750 & 760 & 770 & 780 & 790 & 800 & 810 & 820 & 830 & 840 & 850 & 860 \\
\hline Adjusted $R^{2}$ & 0.7870 & 0.8022 & 0.8109 & 0.8254 & 0.8384 & 0.8467 & 0.8557 & 0.8631 & 0.8688 & 0.8759 & 0.8781 & 0.8781 \\
\hline MSE & 0.00868 & 0.0077 & 0.0099 & 0.0083 & 0.0077 & 0.0066 & 0.007 & 0.0111 & 0.0249 & 0.0226 & 0.0155 & 0.0119 \\
\hline Loss & 1.0611 & 1.0491 & 1.0723 & 1.0574 & 1.0476 & 1.0262 & 0.9832 & 0.9410 & 0.8759 & 0.8811 & 0.9103 & 0.9313 \\
\hline
\end{tabular}

Variables are based on the mean value, by date. 
Table 7: LTV Level

\begin{tabular}{|c|c|c|c|c|c|c|c|c|c|c|c|c|}
\hline & $(1)$ & $(2)$ & (3) & $(4)$ & $(5)$ & $(6)$ & $(7)$ & (8) & $(9)$ & $(10)$ & $(11)$ & $(12)$ \\
\hline DTI, $\operatorname{lag}(1)$ & $\begin{array}{c}0.0008 \\
(0.0018)\end{array}$ & $\begin{array}{c}0.0007 \\
(0.0018)\end{array}$ & $\begin{array}{c}0.0006 \\
(0.0018)\end{array}$ & $\begin{array}{c}0.0005 \\
(0.0019)\end{array}$ & $\begin{array}{c}0.0004 \\
(0.0019)\end{array}$ & $\begin{array}{c}0.0003 \\
(0.0020)\end{array}$ & $\begin{array}{c}0.0001 \\
(0.0021)\end{array}$ & $\begin{array}{l}-0.0001 \\
(0.0021)\end{array}$ & $\begin{array}{l}-0.0001 \\
(0.0023)\end{array}$ & $\begin{array}{l}-0.0001 \\
(0.0024)\end{array}$ & $\begin{array}{l}-0.0002 \\
(0.0024)\end{array}$ & $\begin{array}{l}-0.0004 \\
(0.0025)\end{array}$ \\
\hline HPD, lag(1) & $\begin{array}{c}-0.0073^{*} \\
(0.0037)\end{array}$ & $\begin{array}{c}-0.0083^{* * *} \\
(0.0024)\end{array}$ & $\begin{array}{c}-0.0061^{* *} \\
(0.0019)\end{array}$ & $\begin{array}{c}-0.0078^{* *} \\
(0.0024)\end{array}$ & $\begin{array}{c}-0.0086^{* *} \\
(0.0029)\end{array}$ & $\begin{array}{c}-0.0102^{* * *} \\
(0.0029)\end{array}$ & $\begin{array}{c}-0.0128^{* * *} \\
(0.0032)\end{array}$ & $\begin{array}{c}-0.0143^{* * *} \\
(0.0034)\end{array}$ & $\begin{array}{c}-0.0172^{* * *} \\
(0.0025)\end{array}$ & $\begin{array}{c}-0.0144^{* * *} \\
(0.0023)\end{array}$ & $\begin{array}{c}-0.0119^{* * *} \\
(0.0017)\end{array}$ & $\begin{array}{c}-0.0111^{* * *} \\
(0.0015)\end{array}$ \\
\hline $\mathrm{UR}, \operatorname{lag}(1)$ & $\begin{array}{c}0.0015 \\
(0.0159)\end{array}$ & $\begin{array}{c}0.0024 \\
(0.0117)\end{array}$ & $\begin{array}{l}-0.0018 \\
(0.0103)\end{array}$ & $\begin{array}{c}0.0004 \\
(0.0101)\end{array}$ & $\begin{array}{c}0.0010 \\
(0.0092)\end{array}$ & $\begin{array}{c}0.0029 \\
(0.0092)\end{array}$ & $\begin{array}{c}0.0059 \\
(0.0086)\end{array}$ & $\begin{array}{c}0.0070 \\
(0.0077)\end{array}$ & $\begin{array}{c}0.0097 \\
(0.0110)\end{array}$ & $\begin{array}{c}0.0057 \\
(0.0109)\end{array}$ & $\begin{array}{c}0.0020 \\
(0.0102)\end{array}$ & $\begin{array}{l}-0.0008 \\
(0.0098)\end{array}$ \\
\hline $\mathrm{HPD}^{*} \mathrm{UR}, \operatorname{lag}(1)$ & $\begin{array}{c}0.0030^{* *} \\
(0.0009)\end{array}$ & $\begin{array}{c}0.0032^{* * *} \\
(0.0007)\end{array}$ & $\begin{array}{c}0.0027^{* * *} \\
(0.0005)\end{array}$ & $\begin{array}{c}0.0031^{* * *} \\
(0.0006)\end{array}$ & $\begin{array}{c}0.0032^{* * *} \\
(0.0007)\end{array}$ & $\begin{array}{c}0.0036^{* * *} \\
(0.0007)\end{array}$ & $\begin{array}{c}0.0041^{* * *} \\
(0.0008)\end{array}$ & $\begin{array}{c}0.0044^{* * *} \\
(0.0008)\end{array}$ & $\begin{array}{c}0.0049^{* * *} \\
(0.0008)\end{array}$ & $\begin{array}{c}0.0044^{* * *} \\
(0.0007)\end{array}$ & $\begin{array}{c}0.0039^{* * *} \\
(0.0006)\end{array}$ & $\begin{array}{c}0.0038^{* * *} \\
(0.0006)\end{array}$ \\
\hline Observations & 770 & 780 & 790 & 800 & 810 & 820 & 830 & 840 & 850 & 860 & 870 & 880 \\
\hline Adjusted $R^{2}$ & 0.5324 & 0.5517 & 0.5660 & 0.5828 & 0.5996 & 0.6159 & 0.6387 & 0.6614 & 0.6590 & 0.6615 & 0.6641 & 0.6609 \\
\hline MSE & 0.0158 & 0.0152 & 0.0226 & 0.0192 & 0.0184 & 0.0159 & 0.0135 & 0.0135 & 0.0146 & 0.0136 & 0.015 & 0.0173 \\
\hline Loss & 1.0947 & 1.0888 & 1.1355 & 1.1170 & 1.1119 & 1.0925 & 1.0576 & 1.0427 & 1.0139 & 1.0508 & 1.0838 & 1.1076 \\
\hline
\end{tabular}

Variables are based on the mean value, by date. 
Table 8: FICO Level

\begin{tabular}{|c|c|c|c|c|c|c|c|c|c|c|c|c|}
\hline & (1) & $(2)$ & (3) & (4) & (5) & (6) & $(7)$ & $(8)$ & $(9)$ & $(10)$ & $(11)$ & $(12)$ \\
\hline FICO, lag(1) & $\begin{array}{c}-0.0104^{*} \\
(0.0047)\end{array}$ & $\begin{array}{c}-0.0106^{*} \\
(0.0047)\end{array}$ & $\begin{array}{c}-0.0106^{* *} \\
(0.0047)\end{array}$ & $\begin{array}{c}-0.0108^{* *} \\
(0.0048)\end{array}$ & $\begin{array}{c}-0.0110^{* *} \\
(0.0048)\end{array}$ & $\begin{array}{c}-0.0115^{* *} \\
(0.0049)\end{array}$ & $\begin{array}{c}-0.0122^{* *} \\
(0.0051)\end{array}$ & $\begin{array}{c}-0.0130^{* *} \\
(0.0053)\end{array}$ & $\begin{array}{c}-0.0138^{* *} \\
(0.0057)\end{array}$ & $\begin{array}{c}-0.0138^{* *} \\
(0.0056)\end{array}$ & $\begin{array}{c}-0.0135^{* *} \\
(0.0054)\end{array}$ & $\begin{array}{c}-0.0132^{* *} \\
(0.0054)\end{array}$ \\
\hline DTI, $\operatorname{lag}(1)$ & $\begin{array}{c}0.0161^{* * *} \\
(0.0045)\end{array}$ & $\begin{array}{c}0.0169^{* * *} \\
(0.0046)\end{array}$ & $\begin{array}{c}0.0171^{* * *} \\
(0.0047)\end{array}$ & $\begin{array}{c}0.0179^{* * *} \\
(0.0049)\end{array}$ & $\begin{array}{c}0.0187^{* * *} \\
(0.0052)\end{array}$ & $\begin{array}{c}0.0196^{* * *} \\
(0.0055)\end{array}$ & $\begin{array}{c}0.0208^{* * *} \\
(0.0059)\end{array}$ & $\begin{array}{c}0.0219^{* * *} \\
(0.0063)\end{array}$ & $\begin{array}{c}0.0235^{* * *} \\
(0.0069)\end{array}$ & $\begin{array}{c}0.0243^{* * *} \\
(0.0072)\end{array}$ & $\begin{array}{c}0.0249^{* * *} \\
(0.0074)\end{array}$ & $\begin{array}{c}0.0256^{* * *} \\
(0.0076)\end{array}$ \\
\hline $\mathrm{HPD}, \operatorname{lag}(1)$ & $\begin{array}{c}0.0282^{* *} \\
(0.0119)\end{array}$ & $\begin{array}{l}0.0271^{*} \\
(0.0125)\end{array}$ & $\begin{array}{c}0.0265^{*} \\
(0.0120)\end{array}$ & $\begin{array}{l}0.0261^{*} \\
(0.0120)\end{array}$ & $\begin{array}{l}0.0272^{*} \\
(0.0124)\end{array}$ & $\begin{array}{l}0.0264^{*} \\
(0.0124)\end{array}$ & $\begin{array}{c}0.0269^{*} \\
(0.0127)\end{array}$ & $\begin{array}{c}0.0355^{* *} \\
(0.0143)\end{array}$ & $\begin{array}{c}0.0277^{* *} \\
(0.0118)\end{array}$ & $\begin{array}{c}0.0325^{* *} \\
(0.0134)\end{array}$ & $\begin{array}{c}0.0294^{* *} \\
(0.0123)\end{array}$ & $\begin{array}{c}0.0314^{* *} \\
(0.0125)\end{array}$ \\
\hline $\mathrm{UR}, \operatorname{lag}(1)$ & $\begin{array}{c}0.0160^{* * *} \\
(0.0034)\end{array}$ & $\begin{array}{c}0.0172^{* * *} \\
(0.0031)\end{array}$ & $\begin{array}{c}0.0143^{* * *} \\
(0.0019)\end{array}$ & $\begin{array}{c}0.0148^{* * *} \\
(0.0021)\end{array}$ & $\begin{array}{c}0.0141^{* * *} \\
(0.0021)\end{array}$ & $\begin{array}{c}0.0157^{* * *} \\
(0.0020)\end{array}$ & $\begin{array}{c}0.0201^{* * *} \\
(0.0031)\end{array}$ & $\begin{array}{c}0.0257^{* * *} \\
(0.0039)\end{array}$ & $\begin{array}{c}0.0428^{* * *} \\
(0.0101)\end{array}$ & $\begin{array}{c}0.0402^{* * *} \\
(0.0091)\end{array}$ & $\begin{array}{c}0.0411^{* * *} \\
(0.0096)\end{array}$ & $\begin{array}{c}0.0457^{* * *} \\
(0.0104)\end{array}$ \\
\hline $\mathrm{HPD}, \operatorname{lag}(2)$ & $\begin{array}{c}-0.0385^{*} \\
(0.0201)\end{array}$ & $\begin{array}{c}-0.0363 \\
(0.0209)\end{array}$ & $\begin{array}{l}-0.0334 \\
(0.0194)\end{array}$ & $\begin{array}{l}-0.0326 \\
(0.0195)\end{array}$ & $\begin{array}{c}-0.0351 \\
(0.0202)\end{array}$ & $\begin{array}{l}-0.0344 \\
(0.0202)\end{array}$ & $\begin{array}{c}-0.0368 \\
(0.0211)\end{array}$ & $\begin{array}{c}-0.0524^{*} \\
(0.0239)\end{array}$ & $\begin{array}{l}-0.0305 \\
(0.0174)\end{array}$ & $\begin{array}{c}-0.0415^{*} \\
(0.0199)\end{array}$ & $\begin{array}{c}-0.0353^{*} \\
(0.0178)\end{array}$ & $\begin{array}{c}-0.0378^{*} \\
(0.0181)\end{array}$ \\
\hline $\mathrm{UR}, \operatorname{lag}(2)$ & $\begin{array}{c}0.0225^{* * *} \\
(0.0058)\end{array}$ & $\begin{array}{c}0.0220^{* * *} \\
(0.0056)\end{array}$ & $\begin{array}{c}0.0199^{* * *} \\
(0.0048)\end{array}$ & $\begin{array}{c}0.0210^{* * *} \\
(0.0050)\end{array}$ & $\begin{array}{c}0.0225^{* * *} \\
(0.0049)\end{array}$ & $\begin{array}{c}0.0239^{* * *} \\
(0.0051)\end{array}$ & $\begin{array}{c}0.0258^{* * *} \\
(0.0054)\end{array}$ & $\begin{array}{c}0.0272^{* * *} \\
(0.0056)\end{array}$ & $\begin{array}{c}0.0217^{* * *} \\
(0.0044)\end{array}$ & $\begin{array}{c}0.0188^{* * *} \\
(0.0041)\end{array}$ & $\begin{array}{l}0.0100^{*} \\
(0.0047)\end{array}$ & $\begin{array}{c}0.0007 \\
(0.0046)\end{array}$ \\
\hline 13_hpd & $\begin{array}{c}0.0187 \\
(0.0104)\end{array}$ & $\begin{array}{c}0.0179 \\
(0.0107)\end{array}$ & $\begin{array}{c}0.0155 \\
(0.0096)\end{array}$ & $\begin{array}{c}0.0153 \\
(0.0096)\end{array}$ & $\begin{array}{c}0.0169 \\
(0.0100)\end{array}$ & $\begin{array}{c}0.0172 \\
(0.0101)\end{array}$ & $\begin{array}{c}0.0194 \\
(0.0107)\end{array}$ & $\begin{array}{c}0.0264^{*} \\
(0.0121)\end{array}$ & $\begin{array}{c}0.0121 \\
(0.0082)\end{array}$ & $\begin{array}{l}0.0189^{*} \\
(0.0092)\end{array}$ & $\begin{array}{c}0.0162^{*} \\
(0.0082)\end{array}$ & $\begin{array}{l}0.0170^{*} \\
(0.0084)\end{array}$ \\
\hline Loan Amt, $\operatorname{lag}(1)$ & $\begin{array}{c}-0.2401 \\
(0.1557) \\
\end{array}$ & $\begin{array}{c}-0.2652 \\
(0.1675) \\
\end{array}$ & $\begin{array}{c}-0.2959 \\
(0.1775) \\
\end{array}$ & $\begin{array}{c}-0.3193 \\
(0.1879) \\
\end{array}$ & $\begin{array}{c}-0.3437 \\
(0.1990) \\
\end{array}$ & $\begin{array}{c}-0.3600 \\
(0.2119) \\
\end{array}$ & $\begin{array}{c}-0.3764 \\
(0.2264) \\
\end{array}$ & $\begin{array}{c}-0.3917 \\
(0.2435) \\
\end{array}$ & $\begin{array}{c}-0.4156 \\
(0.2618) \\
\end{array}$ & $\begin{array}{c}-0.4628 \\
(0.2777) \\
\end{array}$ & $\begin{array}{c}-0.5177 \\
(0.2931) \\
\end{array}$ & $\begin{array}{c}-0.5646^{*} \\
(0.3029) \\
\end{array}$ \\
\hline Observations & 750 & 760 & 770 & 780 & 790 & 800 & 810 & 820 & 830 & 840 & 850 & 860 \\
\hline Adjusted $R^{2}$ & 0.5628 & 0.5772 & 0.5894 & 0.6028 & 0.6169 & 0.6300 & 0.6363 & 0.6505 & 0.6531 & 0.6663 & 0.6729 & 0.6776 \\
\hline MSE & 0.0084 & 0.0079 & 0.0127 & 0.0115 & 0.0109 & 0.0084 & 0.0046 & 0.0038 & 0.0069 & 0.0044 & 0.0035 & 0.0048 \\
\hline Loss & 1.069 & 1.0655 & 1.1009 & 1.0953 & 1.0925 & 1.0756 & 1.0346 & 0.9973 & 0.9447 & 0.9694 & 1.0105 & 1.0393 \\
\hline
\end{tabular}

Notes: Robust standard errors in parentheses. $* * * p<0.01, * * p<0.05, * p<0.1$.

Variables are based on the mean value, by date. 
Table 9: County Level

\begin{tabular}{|c|c|c|c|c|c|c|c|c|c|c|c|c|}
\hline & (1) & $(2)$ & (3) & $(4)$ & (5) & (6) & (7) & $(8)$ & (9) & $(10)$ & $(11)$ & $(12)$ \\
\hline HPD, lag(1) & $\begin{array}{l}-0.0016 \\
(0.0023)\end{array}$ & $\begin{array}{c}-0.0038^{*} \\
(0.0023)\end{array}$ & $\begin{array}{l}-0.0031 \\
(0.0022)\end{array}$ & $\begin{array}{l}-0.0040^{*} \\
(0.0022)\end{array}$ & $\begin{array}{c}-0.0039^{*} \\
(0.0022)\end{array}$ & $\begin{array}{c}-0.0041^{* *} \\
(0.0020)\end{array}$ & $\begin{array}{c}-0.0053^{* * *} \\
(0.0020)\end{array}$ & $\begin{array}{c}-0.0068^{* * *} \\
(0.0022)\end{array}$ & $\begin{array}{c}-0.0089^{* * *} \\
(0.0025)\end{array}$ & $\begin{array}{c}-0.0102^{* * *} \\
(0.0024)\end{array}$ & $\begin{array}{c}-0.0122^{* * *} \\
(0.0024)\end{array}$ & $\begin{array}{c}-0.0139^{* * *} \\
(0.0025)\end{array}$ \\
\hline $\mathrm{UR}, \operatorname{lag}(1)$ & $\begin{array}{c}0.0159^{* * *} \\
(0.0053)\end{array}$ & $\begin{array}{c}0.0198^{* * *} \\
(0.0054)\end{array}$ & $\begin{array}{c}0.0178^{* * *} \\
(0.0047)\end{array}$ & $\begin{array}{c}0.0194^{* * *} \\
(0.0048)\end{array}$ & $\begin{array}{c}0.0190^{* * *} \\
(0.0048)\end{array}$ & $\begin{array}{c}0.0189^{* * *} \\
(0.0046)\end{array}$ & $\begin{array}{c}0.0209^{* * *} \\
(0.0044)\end{array}$ & $\begin{array}{c}0.0257^{* * *} \\
(0.0053)\end{array}$ & $\begin{array}{c}0.0292^{* * *} \\
(0.0054)\end{array}$ & $\begin{array}{c}0.0268^{* * *} \\
(0.0054)\end{array}$ & $\begin{array}{c}0.0276^{* * *} \\
(0.0053)\end{array}$ & $\begin{array}{c}0.0302^{* * *} \\
(0.0053)\end{array}$ \\
\hline HPD*UR, lag(1) & $\begin{array}{c}0.0014^{* * *} \\
(0.0004)\end{array}$ & $\begin{array}{c}0.0017^{* * *} \\
(0.0004)\end{array}$ & $\begin{array}{c}0.0016^{* * *} \\
(0.0004)\end{array}$ & $\begin{array}{c}0.0017^{* * *} \\
(0.0004)\end{array}$ & $\begin{array}{c}0.0016^{* * *} \\
(0.0004)\end{array}$ & $\begin{array}{c}0.0015^{* * *} \\
(0.0004)\end{array}$ & $\begin{array}{c}0.0016^{* * *} \\
(0.0004)\end{array}$ & $\begin{array}{c}0.0020^{* * *} \\
(0.0005)\end{array}$ & $\begin{array}{c}0.0023^{* * *} \\
(0.0005)\end{array}$ & $\begin{array}{c}0.0022^{* * *} \\
(0.0005)\end{array}$ & $\begin{array}{c}0.0025^{* * *} \\
(0.0005)\end{array}$ & $\begin{array}{c}0.0028^{* * *} \\
(0.0005)\end{array}$ \\
\hline $\mathrm{HPD}, \operatorname{lag}(2)$ & $\begin{array}{c}0.0035 \\
(0.0023)\end{array}$ & $\begin{array}{c}0.0055^{* *} \\
(0.0022)\end{array}$ & $\begin{array}{c}0.0050^{* *} \\
(0.0023)\end{array}$ & $\begin{array}{c}0.0056^{* *} \\
(0.0022)\end{array}$ & $\begin{array}{c}0.0052^{* *} \\
(0.0022)\end{array}$ & $\begin{array}{c}0.0050^{* *} \\
(0.0021)\end{array}$ & $\begin{array}{c}0.0058^{* * *} \\
(0.0021)\end{array}$ & $\begin{array}{c}0.0070^{* * *} \\
(0.0023)\end{array}$ & $\begin{array}{c}0.0085^{* * *} \\
(0.0027)\end{array}$ & $\begin{array}{c}0.0103^{* * *} \\
(0.0026)\end{array}$ & $\begin{array}{c}0.0129^{* * *} \\
(0.0026)\end{array}$ & $\begin{array}{c}0.0149^{* * *} \\
(0.0025)\end{array}$ \\
\hline $\mathrm{UR}, \operatorname{lag}(2)$ & $\begin{array}{l}-0.0012 \\
(0.0046)\end{array}$ & $\begin{array}{l}-0.0037 \\
(0.0049)\end{array}$ & $\begin{array}{l}-0.0020 \\
(0.0052)\end{array}$ & $\begin{array}{l}-0.0015 \\
(0.0050)\end{array}$ & $\begin{array}{c}0.0009 \\
(0.0044)\end{array}$ & $\begin{array}{c}0.0034 \\
(0.0043)\end{array}$ & $\begin{array}{c}0.0049 \\
(0.0045)\end{array}$ & $\begin{array}{c}0.0038 \\
(0.0052)\end{array}$ & $\begin{array}{c}0.0039 \\
(0.0051)\end{array}$ & $\begin{array}{c}0.0041 \\
(0.0047)\end{array}$ & $\begin{array}{l}-0.0001 \\
(0.0043)\end{array}$ & $\begin{array}{l}-0.0048 \\
(0.0036)\end{array}$ \\
\hline $\mathrm{HPD}^{*} \mathrm{UR}, \operatorname{lag}(2)$ & $\begin{array}{l}-0.0005 \\
(0.0004)\end{array}$ & $\begin{array}{c}-0.0008^{*} \\
(0.0004)\end{array}$ & $\begin{array}{c}-0.0007^{*} \\
(0.0004)\end{array}$ & $\begin{array}{c}-0.0007^{*} \\
(0.0004)\end{array}$ & $\begin{array}{l}-0.0005 \\
(0.0004)\end{array}$ & $\begin{array}{l}-0.0004 \\
(0.0004)\end{array}$ & $\begin{array}{l}-0.0003 \\
(0.0004)\end{array}$ & $\begin{array}{l}-0.0006 \\
(0.0005)\end{array}$ & $\begin{array}{l}-0.0008 \\
(0.0005)\end{array}$ & $\begin{array}{l}-0.0008 \\
(0.0005)\end{array}$ & $\begin{array}{c}-0.0012^{* *} \\
(0.0005)\end{array}$ & $\begin{array}{c}-0.0015^{* * *} \\
(0.0005)\end{array}$ \\
\hline DTI, $\operatorname{lag}(1)$ & $\begin{array}{c}0.0036^{* * *} \\
(0.0005)\end{array}$ & $\begin{array}{c}0.0037^{* * *} \\
(0.0005)\end{array}$ & $\begin{array}{c}0.0037^{* * *} \\
(0.0005)\end{array}$ & $\begin{array}{c}0.0038^{* * *} \\
(0.0005)\end{array}$ & $\begin{array}{c}0.0039^{* * *} \\
(0.0005)\end{array}$ & $\begin{array}{c}0.0040^{* * *} \\
(0.0005)\end{array}$ & $\begin{array}{c}0.0043^{* * *} \\
(0.0005)\end{array}$ & $\begin{array}{c}0.0045^{* * *} \\
(0.0006)\end{array}$ & $\begin{array}{c}0.0047^{* * *} \\
(0.0006)\end{array}$ & $\begin{array}{c}0.0047^{* * *} \\
(0.0006)\end{array}$ & $\begin{array}{c}0.0044^{* * *} \\
(0.0006)\end{array}$ & $\begin{array}{c}0.0043^{* * *} \\
(0.0006)\end{array}$ \\
\hline Observations & 23018 & 23324 & 23630 & 23936 & 24242 & 24548 & 24854 & 25160 & 25466 & 25772 & 26078 & 26384 \\
\hline Adjusted $R^{2}$ & 0.2310 & 0.2546 & 0.2672 & 0.2904 & 0.3119 & 0.3356 & 0.3655 & 0.3945 & 0.4289 & 0.4460 & 0.4554 & 0.4620 \\
\hline MSE & 0.01549 & 0.0132 & 0.0145 & 0.0116 & 0.00893 & 0.0066 & 0.0041 & 0.0036 & 0.0044 & 0.0045 & 0.0041 & 0.0046 \\
\hline Loss & 1.1141 & 1.103 & 1.114 & 1.0980 & 1.0815 & 1.0613 & 1.0294 & 1.0020 & 0.9741 & 0.9806 & 1.0020 & 1.0142 \\
\hline
\end{tabular}

Notes: Standard errors in parentheses. $* * * p<0.01, * * p<0.05, * p<0.1$. Standard errors clustered by county. Fixed Effects included.

Variables are based on the mean value, by date. 
Table 10: Loan Level

\begin{tabular}{|c|c|c|c|c|c|c|c|c|c|c|c|c|}
\hline & $(1)$ & $(2)$ & $(3)$ & $(4)$ & $(5)$ & $(6)$ & $(7)$ & $(8)$ & $(9)$ & $(10)$ & $(11)$ & $(12)$ \\
\hline $\begin{array}{l}\text { delinquent } \\
\text { HPD, } \operatorname{lag}(1)\end{array}$ & $\begin{array}{c}0.0550^{* * *} \\
(0.0020)\end{array}$ & $\begin{array}{c}0.0543^{* * *} \\
(0.0019)\end{array}$ & $\begin{array}{c}0.0536^{* * *} \\
(0.0019)\end{array}$ & $\begin{array}{c}0.0528^{* * *} \\
(0.0018)\end{array}$ & $\begin{array}{c}0.0523^{* * *} \\
(0.0018)\end{array}$ & $\begin{array}{c}0.0512^{* * *} \\
(0.0018)\end{array}$ & $\begin{array}{c}0.0489^{* * *} \\
(0.0018)\end{array}$ & $\begin{array}{c}0.0467^{* * *} \\
(0.0018)\end{array}$ & $\begin{array}{c}0.0447^{* * *} \\
(0.0019)\end{array}$ & $\begin{array}{c}0.0441^{* * *} \\
(0.0020)\end{array}$ & $\begin{array}{c}0.0434^{* * *} \\
(0.0020)\end{array}$ & $\begin{array}{c}0.0429^{* * *} \\
(0.0020)\end{array}$ \\
\hline $\mathrm{UR}, \operatorname{lag}(1)$ & $\begin{array}{c}0.0453^{* * *} \\
(0.0171)\end{array}$ & $\begin{array}{c}0.0467^{* * *} \\
(0.0167)\end{array}$ & $\begin{array}{c}0.0432^{* * *} \\
(0.0155)\end{array}$ & $\begin{array}{c}0.0478^{* * *} \\
(0.0149)\end{array}$ & $\begin{array}{c}0.0517^{* * *} \\
(0.0148)\end{array}$ & $\begin{array}{c}0.0559^{* * *} \\
(0.0148)\end{array}$ & $\begin{array}{c}0.0651^{* * *} \\
(0.0150)\end{array}$ & $\begin{array}{c}0.0768^{* * *} \\
(0.0150)\end{array}$ & $\begin{array}{c}0.0879^{* * *} \\
(0.0152)\end{array}$ & $\begin{array}{c}0.0875^{* * *} \\
(0.0147)\end{array}$ & $\begin{array}{c}0.0901^{* * *} \\
(0.0144)\end{array}$ & $\begin{array}{c}0.0917^{* * *} \\
(0.0142)\end{array}$ \\
\hline win & $\begin{array}{c}0.0217 \\
(0.0797)\end{array}$ & $\begin{array}{c}0.0321 \\
(0.0809)\end{array}$ & $\begin{array}{c}0.0491 \\
(0.0765)\end{array}$ & $\begin{array}{c}0.0547 \\
(0.0754)\end{array}$ & $\begin{array}{c}0.0385 \\
(0.0731)\end{array}$ & $\begin{array}{c}0.0242 \\
(0.0726)\end{array}$ & $\begin{array}{c}-0.0105 \\
(0.0686)\end{array}$ & $\begin{array}{c}-0.0165 \\
(0.0679)\end{array}$ & $\begin{array}{c}-0.0292 \\
(0.0684)\end{array}$ & $\begin{array}{c}-0.0385 \\
(0.0672)\end{array}$ & $\begin{array}{c}-0.0511 \\
(0.0687)\end{array}$ & $\begin{array}{l}-0.0615 \\
(0.0677)\end{array}$ \\
\hline Appraisal (mil.) & $\begin{array}{c}0.0004^{* * *} \\
(0.0001)\end{array}$ & $\begin{array}{c}0.0004^{* * *} \\
(0.0001)\end{array}$ & $\begin{array}{c}0.0005^{* * *} \\
(0.0001)\end{array}$ & $\begin{array}{c}0.0005^{* * *} \\
(0.0001)\end{array}$ & $\begin{array}{c}0.0005^{* * *} \\
(0.0001)\end{array}$ & $\begin{array}{c}0.0005^{* * *} \\
(0.0001)\end{array}$ & $\begin{array}{c}0.0005^{* * *} \\
(0.0001)\end{array}$ & $\begin{array}{c}0.0005^{* * *} \\
(0.0001)\end{array}$ & $\begin{array}{c}0.0005^{* * *} \\
(0.0001)\end{array}$ & $\begin{array}{c}0.0005^{* * *} \\
(0.0001)\end{array}$ & $\begin{array}{c}0.0005^{* * *} \\
(0.0001)\end{array}$ & $\begin{array}{c}0.0005^{* * *} \\
(0.0001)\end{array}$ \\
\hline Full Doc. $(\mathrm{D}=1)$ & $\begin{array}{c}-0.3492^{* * *} \\
(0.0515)\end{array}$ & $\begin{array}{c}-0.3728^{* * *} \\
(0.0513)\end{array}$ & $\begin{array}{c}-0.3832^{* * *} \\
(0.0518)\end{array}$ & $\begin{array}{c}-0.4018^{* * *} \\
(0.0512)\end{array}$ & $\begin{array}{c}-0.4213^{* * *} \\
(0.0509)\end{array}$ & $\begin{array}{c}-0.4504^{* * *} \\
(0.0510)\end{array}$ & $\begin{array}{c}-0.4504^{* * *} \\
(0.0508)\end{array}$ & $\begin{array}{c}-0.4534^{* * *} \\
(0.0511)\end{array}$ & $\begin{array}{c}-0.4662^{* * *} \\
(0.0519)\end{array}$ & $\begin{array}{c}-0.4657^{* * *} \\
(0.0511)\end{array}$ & $\begin{array}{c}-0.4695^{* * *} \\
(0.0501)\end{array}$ & $\begin{array}{c}-0.4642^{* * *} \\
(0.0511)\end{array}$ \\
\hline Interest $\operatorname{Only}(\mathrm{D}=1)$ & $\begin{array}{c}-1.8574^{* * *} \\
(0.0721)\end{array}$ & $\begin{array}{c}-1.9012^{* * *} \\
(0.0752)\end{array}$ & $\begin{array}{c}-1.9316^{* * *} \\
(0.0763)\end{array}$ & $\begin{array}{c}-1.9770^{* * *} \\
(0.0775)\end{array}$ & $\begin{array}{c}-2.0378^{* * *} \\
(0.0792)\end{array}$ & $\begin{array}{c}-2.0991^{* * *} \\
(0.0797)\end{array}$ & $\begin{array}{c}-2.1729^{* * *} \\
(0.0802)\end{array}$ & $\begin{array}{c}-2.2478^{* * *} \\
(0.0828)\end{array}$ & $\begin{array}{c}-2.3187^{* * *} \\
(0.0851)\end{array}$ & $\begin{array}{c}-2.3602^{* * *} \\
(0.0842)\end{array}$ & $\begin{array}{c}-2.3885^{* * *} \\
(0.0801)\end{array}$ & $\begin{array}{c}-2.4405^{* * *} \\
(0.0821)\end{array}$ \\
\hline Margin Rate & $\begin{array}{l}-0.0104 \\
(0.0153)\end{array}$ & $\begin{array}{l}-0.0154 \\
(0.0158)\end{array}$ & $\begin{array}{c}-0.0166 \\
(0.0156)\end{array}$ & $\begin{array}{l}-0.0138 \\
(0.0152)\end{array}$ & $\begin{array}{l}-0.0080 \\
(0.0149)\end{array}$ & $\begin{array}{c}0.0018 \\
(0.0147)\end{array}$ & $\begin{array}{c}0.0107 \\
(0.0152)\end{array}$ & $\begin{array}{c}0.0168 \\
(0.0150)\end{array}$ & $\begin{array}{c}0.0149 \\
(0.0150)\end{array}$ & $\begin{array}{c}0.0147 \\
(0.0150)\end{array}$ & $\begin{array}{c}0.0154 \\
(0.0148)\end{array}$ & $\begin{array}{c}0.0117 \\
(0.0148)\end{array}$ \\
\hline Loan Amt & $\begin{array}{c}0.2441^{* * *} \\
(0.0215)\end{array}$ & $\begin{array}{c}0.2423^{* * *} \\
(0.0191)\end{array}$ & $\begin{array}{c}0.2450^{* * *} \\
(0.0175)\end{array}$ & $\begin{array}{c}0.2442^{* * *} \\
(0.0175)\end{array}$ & $\begin{array}{c}0.2456^{* * *} \\
(0.0166)\end{array}$ & $\begin{array}{c}0.2420^{* * *} \\
(0.0160)\end{array}$ & $\begin{array}{c}0.2384^{* * *} \\
(0.0157)\end{array}$ & $\begin{array}{c}0.2339^{* * *} \\
(0.0145)\end{array}$ & $\begin{array}{c}0.2400^{* * *} \\
(0.0135)\end{array}$ & $\begin{array}{c}0.2384^{* * *} \\
(0.0124)\end{array}$ & $\begin{array}{c}0.2374^{* * *} \\
(0.0116)\end{array}$ & $\begin{array}{c}0.2375^{* * *} \\
(0.0112)\end{array}$ \\
\hline $\operatorname{Purchase}(\mathrm{D}=1)$ & $\begin{array}{c}0.2603^{* * *} \\
(0.0653)\end{array}$ & $\begin{array}{c}0.3417^{* * *} \\
(0.0632)\end{array}$ & $\begin{array}{c}0.3652^{* * *} \\
(0.0620)\end{array}$ & $\begin{array}{c}0.4032^{* * *} \\
(0.0603)\end{array}$ & $\begin{array}{c}0.4085^{* * *} \\
(0.0563)\end{array}$ & $\begin{array}{c}0.4225^{* * *} \\
(0.0495)\end{array}$ & $\begin{array}{c}0.4166^{* * *} \\
(0.0488)\end{array}$ & $\begin{array}{c}0.4536^{* * *} \\
(0.0491)\end{array}$ & $\begin{array}{c}0.4847^{* * *} \\
(0.0463)\end{array}$ & $\begin{array}{c}0.4674^{* * *} \\
(0.0454)\end{array}$ & $\begin{array}{c}0.4763^{* * *} \\
(0.0466)\end{array}$ & $\begin{array}{c}0.5016^{* * *} \\
(0.0448)\end{array}$ \\
\hline Loan Term & $\begin{array}{c}-0.0019^{* * *} \\
(0.0002)\end{array}$ & $\begin{array}{c}-0.0021^{* * *} \\
(0.0002)\end{array}$ & $\begin{array}{c}-0.0021^{* * *} \\
(0.0002)\end{array}$ & $\begin{array}{c}-0.0022^{* * *} \\
(0.0002)\end{array}$ & $\begin{array}{c}-0.0023^{* * *} \\
(0.0002)\end{array}$ & $\begin{array}{c}-0.0024^{* * *} \\
(0.0002)\end{array}$ & $\begin{array}{c}-0.0025^{* * *} \\
(0.0002)\end{array}$ & $\begin{array}{c}-0.0026^{* * *} \\
(0.0002)\end{array}$ & $\begin{array}{c}-0.0028^{* * *} \\
(0.0002)\end{array}$ & $\begin{array}{c}-0.0029^{* * *} \\
(0.0002)\end{array}$ & $\begin{array}{c}-0.0030^{* * *} \\
(0.0002)\end{array}$ & $\begin{array}{c}-0.0031^{* * *} \\
(0.0002)\end{array}$ \\
\hline Current IR & $\begin{array}{c}0.2514^{* * *} \\
(0.0090)\end{array}$ & $\begin{array}{c}0.2472^{* * *} \\
(0.0092)\end{array}$ & $\begin{array}{c}0.2502^{* * *} \\
(0.0092)\end{array}$ & $\begin{array}{c}0.2478^{* * *} \\
(0.0094)\end{array}$ & $\begin{array}{c}0.2455^{* * *} \\
(0.0089)\end{array}$ & $\begin{array}{c}0.2366^{* * *} \\
(0.0088)\end{array}$ & $\begin{array}{c}0.2197^{* * *} \\
(0.0089)\end{array}$ & $\begin{array}{c}0.2049^{* * *} \\
(0.0090)\end{array}$ & $\begin{array}{c}0.1976^{* * *} \\
(0.0091)\end{array}$ & $\begin{array}{c}0.1931^{* * *} \\
(0.0092)\end{array}$ & $\begin{array}{c}0.1928^{* * *} \\
(0.0093)\end{array}$ & $\begin{array}{c}0.1908^{* * *} \\
(0.0093)\end{array}$ \\
\hline DTI & $\begin{array}{c}-0.0023^{* *} \\
(0.0012)\end{array}$ & $\begin{array}{c}-0.0026^{* *} \\
(0.0012)\end{array}$ & $\begin{array}{c}-0.0029^{* *} \\
(0.0012)\end{array}$ & $\begin{array}{c}-0.0029^{* * *} \\
(0.0011)\end{array}$ & $\begin{array}{c}-0.0031^{* * *} \\
(0.0011)\end{array}$ & $\begin{array}{c}-0.0031^{* * *} \\
(0.0010)\end{array}$ & $\begin{array}{c}-0.0031^{* * *} \\
(0.0010)\end{array}$ & $\begin{array}{c}-0.0029^{* * *} \\
(0.0010)\end{array}$ & $\begin{array}{c}-0.0027^{* * *} \\
(0.0010)\end{array}$ & $\begin{array}{c}-0.0026^{* * *} \\
(0.0009)\end{array}$ & $\begin{array}{c}-0.0027^{* * *} \\
(0.0009)\end{array}$ & $\begin{array}{c}-0.0026^{* * *} \\
(0.0009)\end{array}$ \\
\hline Committed & $\begin{array}{c}0.6307^{* * *} \\
(0.0179)\end{array}$ & $\begin{array}{c}0.6370^{* * *} \\
(0.0177)\end{array}$ & $\begin{array}{c}0.6449^{* * *} \\
(0.0174)\end{array}$ & $\begin{array}{c}0.6481^{* * *} \\
(0.0172)\end{array}$ & $\begin{array}{c}0.6565^{* * *} \\
(0.0167)\end{array}$ & $\begin{array}{c}0.6619^{* * *} \\
(0.0165)\end{array}$ & $\begin{array}{c}0.6605^{* * *} \\
(0.0162)\end{array}$ & $\begin{array}{c}0.6654^{* * *} \\
(0.0169)\end{array}$ & $\begin{array}{c}0.6697^{* * *} \\
(0.0165)\end{array}$ & $\begin{array}{c}0.6740^{* * *} \\
(0.0155)\end{array}$ & $\begin{array}{c}0.6760^{* * *} \\
(0.0156)\end{array}$ & $\begin{array}{c}0.6788^{* * *} \\
(0.0151)\end{array}$ \\
\hline Constant & $\begin{array}{c}-9.0459^{* * *} \\
(1.6328)\end{array}$ & $\begin{array}{c}-8.8904^{* * *} \\
(1.6499)\end{array}$ & $\begin{array}{c}-8.9194^{* * *} \\
(1.5915)\end{array}$ & $\begin{array}{c}-8.8802^{* * *} \\
(1.5381)\end{array}$ & $\begin{array}{c}-8.4734^{* * *} \\
(1.5071)\end{array}$ & $\begin{array}{c}-8.8679^{* * *} \\
(1.5370)\end{array}$ & $\begin{array}{c}-8.4449^{* * *} \\
(1.6041)\end{array}$ & $\begin{array}{c}-8.8562^{* * *} \\
(1.5397)\end{array}$ & $\begin{array}{c}-9.2848^{* * *} \\
(1.5333)\end{array}$ & $\begin{array}{c}-9.2778^{* * *} \\
(1.4969)\end{array}$ & $\begin{array}{c}-9.3871^{* * *} \\
(1.4896)\end{array}$ & $\begin{array}{c}-9.4173^{* * *} \\
(1.4465)\end{array}$ \\
\hline Observations & 5438690 & 5568757 & 5698048 & 5826645 & 5954505 & 6081629 & 6208287 & 6333879 & 6458268 & 6581310 & 6702895 & 6818612 \\
\hline Pseudo $R^{2}$ & 0.1744 & 0.1785 & 0.1805 & 0.1843 & 0.1887 & 0.1919 & 0.1961 & 0.2002 & 0.2041 & 0.2063 & 0.2079 & 0.2100 \\
\hline MSE & 0.0855 & 0.0842 & 0.0900 & 0.0882 & 0.0858 & 0.0779 & 0.0617 & 0.0426 & 0.0290 & 0.0246 & 0.0201 & 0.01804 \\
\hline Loss & 1.3202 & 1.3200 & 1.3381 & 1.3370 & 1.334 & 1.316 & 1.2754 & 1.2212 & 1.1759 & 1.1577 & 1.1390 & 1.1288 \\
\hline
\end{tabular}

Notes: County clustered standard errors in parentheses. $* * * p<0.01, * * p<0.05, * p<0.1$

Vintage Fixed Effects, FICO/LTV/age splines 